University of Vermont

UVM ScholarWorks

Rubenstein School of Environment and Natural Rubenstein School of Environment and Natural Resources Faculty Publications

$10-1-2012$

\title{
Bioenergy harvesting impacts on ecologically important stand structure and habitat characteristics
}

\author{
Caitlin E. Littlefield \\ University of Vermont \\ William S. Keeton \\ University of Vermont
}

Follow this and additional works at: https://scholarworks.uvm.edu/rsfac

Part of the Agriculture Commons, Climate Commons, and the Sustainability Commons

\section{Recommended Citation}

Littlefield CE, Keeton WS. Bioenergy harvesting impacts on ecologically important stand structure and habitat characteristics. Ecological Applications. 2012 Oct;22(7):1892-909.

This Article is brought to you for free and open access by the Rubenstein School of Environment and Natural Resources at UVM ScholarWorks. It has been accepted for inclusion in Rubenstein School of Environment and Natural Resources Faculty Publications by an authorized administrator of UVM ScholarWorks. For more information, please contact scholarworks@uvm.edu. 


\title{
Bioenergy harvesting impacts on ecologically important stand structure and habitat characteristics
}

\author{
Caitlin E. Littlefield and William S. Keeton ${ }^{1}$ \\ Rubenstein School of Environment and Natural Resources, University of Vermont, 81 Carrigan Drive, \\ Burlington, Vermont 05405 USA
}

\begin{abstract}
Demand for forest bioenergy fuel is increasing in the northern forest region of eastern North America and beyond, but ecological impacts, particularly on habitat, of bioenergy harvesting remain poorly explored in the peer-reviewed literature. Here, we evaluated the impacts of bioenergy harvests on stand structure, including several characteristics considered important for biodiversity and habitat functions. We collected stand structure data from 35 recent harvests in northern hardwood-conifer forests, pairing harvested areas with unharvested reference areas. Biometrics generated from field data were analyzed using a multi-tiered nonparametric uni- and multivariate statistical approach. In analyses comparing harvested to reference areas, sites that had been whole-tree harvested demonstrated significant differences (relative negative contrasts, $P<0.05$ ) in snag density, large live-tree density, well-decayed downed coarse woody debris volume, and structural diversity index $(H)$ values, while sites that had not been whole-tree harvested did not exhibit significant differences. Classification and regression tree (CART) analyses suggested that the strongest predictors of structural retention, as indicated by downed woody debris volumes and $H$ index, were silvicultural treatment and equipment type rather than the percentage of harvested volume allocated to bioenergy uses. In general, bioenergy harvesting impacts were highly variable across the study sites, suggesting a need for harvesting guidelines aimed at encouraging retention of ecologically important structural attributes.
\end{abstract}

Key words: bioenergy; biomass harvesting; harvesting guidelines; northern hardwoods; stand structure; structural complexity; structural indicators; sustainable forestry; temperate forests, eastern North America; whole-tree harvesting; woodfuel harvesting.

\section{INTRODUCTION}

Interest in forest bioenergy fuel is increasing in the northeastern United States and beyond. Yet the question of how to harvest woody biomass in an ecologically sustainable manner continues to frame policy debates regarding expanded use of bioenergy (Buccholz et al. 2009, Lattimore et al. 2009, Gunn et al. 2012). The perceived benefits of this energy resource (e.g., local availability, renewable energy independence) must be evaluated against the potential for elevated harvest-induced stress on forest ecosystems, particularly if harvesting intensity increases with associated impacts on ecologically important elements of stand structure (Van Hook et al. 1982, Lattimore et al. 2009, Janowiak and Webster 2010). Alternatively, silvicultural treatments that remove low-grade materials may improve forest stand conditions and habitat development potential (Sabourin et al. 1992, Manley and Richardson 1995, Crow et al. 2002).

Only a limited number of data sets are available for temperate forests that specifically quantify bioenergy

Manuscript received 2 December 2011; revised 16 April 2012; accepted 23 April 2012. Corresponding Editor: A. D. McGuire.

${ }^{1}$ Corresponding author.E-mail: William.keeton@uvm.edu harvesting impacts on stand structure (e.g., Chadwick et al. 1986, Demchik et al. 2009, Evans and Finkral 2009), the most recent of which describes retention levels following whole-tree harvests in various forest types in central Maine, USA (Briedis et al. 2011). Consequently, the degree to which a range of bioenergy harvesting intensities and treatment types may impact stand structure remains uncertain and is the focus of our study. Our objective is to empirically evaluate the effects of harvesting forest bioenergy fuel on ecologically important elements of stand structure in the temperate northern forests of eastern North America.

\section{Evaluating structural complexity}

Numerous forest stand structure attributes have been recognized as indicators of ecosystem functionality and biodiversity in the northern hardwood forests and beyond (Harmon et al. 1986, Keddy and Drummond 1996, DeGraaf et al. 1998, Spies 1998). Such attributes may include measures of abundance (e.g., volumes of dead wood); relative abundance (e.g., comparative basal areas by tree species); richness (e.g., species richness); size and age variation (e.g., densities of large trees); or spatial variation and pattern (e.g., tree spacing and patch mosaics) (Angers et al. 2005, McElhinny et al. 2005, Keeton et al. 2007, Manaras-Smith et al. 2008). 
Structural complexity reflects the aggregate heterogeneity of horizontal and vertical stand structure and how structural elements - of varying size and abundanceare distributed in space (i.e., spatial heterogeneity; Oliver and Larson 1996, Pommerening 2002, McElhinny et al. 2005). Because measuring structural complexity inherently involves interactions among multiple structural elements, many different indices have been developed that attempt to express aggregate structural complexity as a single metric to facilitate, for instance, comparisons and rankings (Staudhammer and LeMay 2001, Pommerening 2002, McElhinny et al. 2005). Reflecting previous research, our study employs a suite of stand structural indicators, including stocking metrics, diameter distributions, volumes of downed woody debris, and densities of downed crowns. We also apply a modified Shannon-Wiener diversity index, $H$, that describes in a single number how basal area is apportioned by species and size class (Staudhammer and LeMay 2001, Leniere and Houle 2006). The index integrates several aspects of structural complexity, thereby complementing the metrics quantifying specific structural characteristics.

\section{Silvicultural impacts on stand structure and ecological functioning}

A concern articulated in some policy discussions is that increased long-term demand for forest bioenergy fuel regionally and globally may result in harvesting operations that reduce the availability of, or impair the recruitment of, stand-structure elements that are important in ecological functioning, especially habitat provisioning. Stand structure may be particularly susceptible because bioenergy harvesting may target otherwise unmerchantable materials typically not removed by conventional (i.e., non-bioenergy) harvests (Evans and Finkral 2009). In particular, more frequent harvests, whole-tree harvests, intensive thinning that removes "cull" trees of poor form or low vigor, and removals or manipulations of dead wood may impact key elements of stand structure, for instance, by impairing snag and downed-wood recruitment (Goodburn and Lorimer 1998, Crow et al. 2002, Evans and Finkral 2009, Lattimore et al. 2009). Alternatively, bioenergy harvests conducted primarily as stand-improvement cuttings (e.g., pre-commercial thinning) may improve aspects of stand structure (e.g., stocking, mean diameter), stem quality, and individual tree growth (Sabourin et al. 1992, Manley and Richardson 1995).

Structural complexity in temperate forest ecosystems is widely associated with a variety of habitat-related functions (Harmon et al. 1986, McKenny et al. 2006, Keeton et al. 2007). In addition to standing live trees, both standing snags and downed dead wood-including downed coarse woody debris (DCWD) and fine woody debris (FWD) - play significant roles (e.g., for reproduction, feeding) in habitat provisioning for fungi, plants, invertebrates, and vertebrates. Downed logs can serve as establishment sites (i.e., "nurse logs") for regenerating vegetation, such as yellow birch (Betula alleghaniensis) and red spruce (Picea rubens) (McGee and Birmingham 1997). Saproxylic insect species are dependent upon dead and decaying wood and have been found-along with other invertebrates - to respond strongly to DCWD and FWD volumes and connectivity post-harvest in temperate forest ecosystems (Schiegg 2000, Spence et al. 2007). Similarly, studies have shown population abundances for a variety of temperate forest amphibian and small-mammal species to be positively correlated with post-harvest DCWD and FWD volumes and availability of well-decayed logs (Freedman et al. 1996, Bowman et al. 2000, McKenny et al. 2006). This also holds for some interior-dwelling understory herbaceous plants, though these are also strongly influenced by canopy structure (Smith et al. 2008).

Dead wood can also be a critical habitat element in forest streams because, among other functions, debris dams retain organic matter and contribute to pool formation (Bilby and Likens 1980, Harmon et al. 1986, Keeton et al. 2007). Many species use snags for foraging, nesting, and roosting; snag retention in northern hardwood forests is consistently correlated with increased biodiversity and abundance, particularly for birds (Chadwick et al. 1986, DeGraaf et al. 1998). In light of the ecological functions provided by standing and downed dead wood, a primary objective of this study is to examine bioenergy harvesting impacts on these structural elements.

Previous and ongoing research around the world is investigating the question of whether whole-tree harvesting (i.e., the removal of all aboveground portions of a tree, including bole, branches, and tops) has the potential to impair nutrient availability, induce soil compaction, and retard residual tree growth, particularly over multiple rotations, during the growing season, and on poor or calcium-depleted sites (Hornbeck et al. 1990, Han et al. 2009, Helmisaari et al. 2011, Thiffault et al. 2011). A consistent harvest-induced reduction in stand structural elements such as standing and downed dead wood may represent a lasting depletion of in situ carbon storage if repeated over multiple rotations (Harmon et al. 1990, Krankina and Harmon 1994, Harmon and Marks 2002). These areas of investigation are important for developing a comprehensive understanding of bioenergy harvesting impacts in a range of ecosystem types. Our study, however, was focused on stand structure and, more specifically, structural complexity in an effort to inform that larger context.

\section{Research context and objectives}

Over the past two decades reviews have synthesized the global body of literature addressing harvesting impacts on forest structure and made inferences about the possible impacts of bioenergy harvesting specifically (e.g., Smith 1995, Freedman et al. 1996, Lattimore et al. 2009, Abbas et al. 2011). Concurrently, research 
institutes, industry groups, end users (e.g, utilities), and government agencies - in the United States and abroad - have issued guidelines and procurement standards for bioenergy harvesting (e.g., Richardson et al. 2002, Evans and Perschel 2009, Janowiak and Webster 2010, Manomet Center for Conservation Sciences 2010). For example, at least six U.S. states (Maine, Michigan, Missouri, Minnesota, Pennsylvania, and Wisconsin) have developed guidelines addressing structural retention in bioenergy harvests specifically, as have other temperate nations, such as Sweden, Finland, and Lithuania (Stupak et al. 2007).

Of limited availability in the literature are empirical data from direct investigations of the effects of bioenergy harvesting on stand structure, though some data are now available from Maine addressing retention levels after bioenergy whole-tree harvests in a range of forest types (Briedis et al. 2011). Other notable exceptions have evaluated bioenergy harvesting in conjunction with forest fire risk and ladder-fuel reduction throughout western, southwestern, and northern states (Demchik et al. 2009, Evans and Finkral 2009). Researchers in Nordic boreal forests have examined long-term bioenergy-harvesting impacts on volume increment (Helmisaari et al. 2011). To the best of our knowledge though, most current research efforts estimating or predicting bioenergy harvesting impacts are either manipulative (e.g., artificial slash retention and removal), involve simulation modeling, or do not specifically address stand structure.

One reason for the relative scarcity of empirical field data may be that bioenergy harvesting in the northern hardwood region is typically conducted jointly with - or secondarily to - other objectives, including commercial sawlog harvesting and stand regeneration (Sabourin et al. 1992, Manley and Richardson 1995, Cook and O'Laughlin 2011). This contrasts with biomass removed in fuels-treatment operations in fire-suppressed western coniferous forests where small-diameter, low-grade material may comprise most or all volume removed (Allen et al. 2002). However, in the northern hardwood region, the lack of uniformity in bioenergy harvesting may confound controlled data collection (Evans and Finkral 2009).

Our study aims to address this knowledge gap by analyzing field data collected from recent bioenergy harvests as opposed to relying on inference from nonbioenergy harvesting studies, site manipulation (e.g., artificial slash retention and removal), or simulation modeling. We know of no studies that specifically quantify downed-tree crown densities as we do, though felled crown retention is a concern for whole-tree harvesting especially (Lattimore et al. 2009).

In addition to assessing impacts of bioenergy harvesting on stand structure, we investigated which harvest- and site-specific variables (e.g., harvesting equipment, ownership, certification) best predict post-harvest structure. Whole-tree harvests were hypothesized to result in significantly reduced representation of ecologically important elements of stand structure, compared to nonwhole-tree harvests. Measures of harvest intensity - as reflected in treatment type, equipment, percentage of harvested volume to bioenergy, and so forth-were hypothesized to be the best predictors of post-harvest stand structure. A robust understanding of both the structural impacts of bioenergy harvesting and the strongest determinants of post-harvest structure will inform harvesting guidelines and procurement standards and to improve projections of forest-based bioenergy supplies in light of structural retention recommendations.

\section{Methods}

\section{Study area and site selection}

Our study area encompassed a representative portion of the temperate northern hardwood and mixed hardwood-conifer region of the northeastern United States, specifically the eastern Adirondack region of New York and central to northern Vermont and New Hampshire. Dominant late-successional species in these forests include Acer saccharum (sugar maple), Fagus grandifolia (American beech), Betula alleghaniensis (yellow birch), and Tsuga canadensis (eastern hemlock), with smaller components of Acer rubrum (red maple), Pinus strobus (white pine), Picea rubens (red spruce), and Quercus rubra (red oak).

To identify candidate study sites, a mail survey was sent to over 115 professional foresters soliciting information about recent harvests from which woody biomass had been removed for bioenergy purposes (i.e., for wood chip or pellet systems; cordwood was not considered in our site-selection process; see Plate 1). One-quarter of the foresters responded, and many offered access to sites that had been recently harvested for bioenergy. We evaluated the candidate study sites with the intention of reducing variability associated with species composition, stand age, edaphic and topographic characteristics, and management history. Specific criteria included the following: (1) northern hardwood or northern hardwood-conifer; (2) mature $(\sim 50-100$ years old); (3) moderate to high site productivity (sugar maple site class 1-3); (4) low to moderate elevation $(<600 \mathrm{~m})$; (5) not a plantation; (6) partially harvested (i.e., not clear-cut) within the prior 3 years. Through this evaluation process we identified 35 sites as suitable for the purposes of this study (Table 1; Fig. 1). To compensate for potential limitations of this sample size, we used a standardized comparison metric, treated response variables as continuous, and employed nonparametric statistical tests.

Six of the sites had no portion of the harvested volume allocated to bioenergy; none of this subset was whole-tree harvested. Of the twenty-nine sites that had some of the harvested volume allocated to bioenergy, four were not whole-tree harvested, but had bole material chipped for bioenergy uses. The 29 bioenergy sites spanned a continuum of volume allocation to 
TABLE 1. Pre-harvest site information and characteristics for the 35 sites in our study, chosen to be representative of the temperate northern hardwood or hardwood-conifer region of the northeastern United States.

\begin{tabular}{|c|c|c|c|c|c|c|c|c|c|}
\hline $\begin{array}{l}\text { Site } \\
\text { ID }\end{array}$ & $\begin{array}{l}\text { Elev. } \\
(\mathrm{m})\end{array}$ & $\begin{array}{c}\text { Slope } \\
(\%)\end{array}$ & $\begin{array}{c}\text { Aspect } \\
\left({ }^{\circ}\right)\end{array}$ & $\begin{array}{c}\text { Conifer } \\
\text { component } \\
(\% \text { BA })\end{array}$ & $\begin{array}{l}\text { Basal area, BA } \\
\left(\mathrm{m}^{2} / \mathrm{ha}\right)\end{array}$ & $\begin{array}{l}\text { QMD } \\
(\mathrm{cm}) \dagger\end{array}$ & $\begin{array}{c}\text { Canopy cover } \\
(\%)\end{array}$ & Ownership & $\begin{array}{c}\text { Current } \\
\text { primary management }\end{array}$ \\
\hline ATH & 233 & 23.1 & 234 & 29.3 & 24.6 & 23.9 & 67 & private & sugarbush \\
\hline BEL & 542 & 17.6 & 243 & 7.9 & 28.9 & 19.8 & 80 & private & sugarbush \\
\hline BLU & 219 & 17.6 & 50 & 8.9 & 25.8 & 17.6 & 84 & private & timberland \\
\hline BRA & 277 & 15.8 & 179 & 3.4 & 27.1 & 20.9 & 84 & private & sugarbush \\
\hline BRI & 596 & 24.9 & 30 & 10.7 & 32.1 & 16.7 & 95 & public & timberland \\
\hline DOD & 165 & 5.2 & 205 & 50.5 & 46.4 & 27.4 & 97 & private & timberland \\
\hline DUM & 439 & 10.5 & 96 & 9.6 & 27.9 & 17.7 & 78 & private & sugarbush \\
\hline FEA & 230 & 7.0 & 114 & 26.2 & 26.2 & 23.9 & 71 & private & timberland \\
\hline FOS & 155 & 14.1 & 245 & 43.5 & 31.7 & 30.0 & 83 & private & timberland \\
\hline GER & 156 & 12.3 & 326 & 41.2 & 15.6 & 21.3 & 46 & private & sugarbush \\
\hline GOL & 244 & 10.5 & 183 & 5.5 & 31.6 & 19.0 & 88 & private & timberland \\
\hline GRO & 407 & 21.3 & 26 & 52.1 & 33.5 & 16.1 & 86 & public & sugarbush \\
\hline HA1 & 292 & 10.5 & 66 & 18.1 & 38.1 & 19.4 & 96 & private & timberland \\
\hline HA2 & 306 & 0.0 & 139 & 73.3 & 39.5 & 26.7 & 85 & private & timberland \\
\hline KEE & 538 & 48.8 & 53 & 1.7 & 26.6 & 21.0 & 88 & private & timberland \\
\hline MAR & 209 & 3.5 & 39 & 10.9 & 31.6 & 18.7 & 93 & private & sugarbush \\
\hline MIL & 467 & 19.4 & 156 & 43.9 & 23.5 & 17.1 & 69 & public & recreation \\
\hline MIS & 377 & 3.5 & 147 & 3.2 & 28.5 & 21.8 & 91 & private & timberland \\
\hline MON & 385 & 14.1 & 265 & 17.6 & 19.5 & 19.7 & 59 & private & timberland \\
\hline NA1 & 438 & 8.7 & 280 & 9.4 & 29.4 & 18.1 & 80 & public & timberland \\
\hline NA2 & 422 & 12.3 & 212 & 0 & 28 & 21.7 & 88 & public & timberland \\
\hline NIC & 248 & 12.3 & 221 & 0 & 26.4 & 21.6 & 87 & private & timberland \\
\hline NOP & 315 & 10.5 & 229 & 33.9 & 22.6 & 24.1 & 64 & private & timberland \\
\hline NOU & 542 & 19.4 & 189 & 4.7 & 29.4 & 25.1 & 89 & private & timberland \\
\hline OSB & 434 & 7.0 & 244 & 0 & 35 & 21.7 & 94 & private & timberland \\
\hline PAG & 478 & 8.7 & 253 & 8.3 & 20.7 & 13.7 & 67 & private & timberland \\
\hline RIE & 135 & 23.1 & 47 & 49.2 & 37.3 & 22.8 & 93 & private & timberland \\
\hline SAN & 544 & 12.3 & 235 & 4.4 & 31.2 & 17.6 & 98 & private & timberland \\
\hline $\mathrm{SCO}$ & 269 & 10.5 & 240 & 27.6 & 34.9 & 20.7 & 86 & private & timberland \\
\hline TIM & 397 & 21.3 & 181 & 5.1 & 22.4 & 17.1 & 72 & private & timberland \\
\hline TIV & 393 & 19.4 & 75 & 0 & 23.9 & 20.6 & 81 & private & timberland \\
\hline TRE & 463 & 3.5 & 77 & 25.4 & 27.1 & 13.7 & 80 & private & timberland \\
\hline VL1 & 333 & 8.7 & 254 & 3.1 & 29.8 & 16.9 & 91 & private & timberland \\
\hline VL2 & 415 & 21.3 & 32 & 2.3 & 19.7 & 15.4 & 65 & private & timberland \\
\hline WAS & 601 & 14.1 & 223 & 3.3 & 28 & 18.6 & 93 & public & timberland \\
\hline Mean & 362 & 14.1 & n.a. & 18.1 & 28.7 & 20.2 & 82 & n.a. & n.a. \\
\hline
\end{tabular}

Note: The abbreviation "n.a." means not applicable.

$\dagger$ The quadratic mean diameter (QMD) is the diameter of the tree of average basal area.

bioenergy, which represents the diversity of harvesting objectives in this region, wherein woody biomass is typically one component of a larger mix of products. The majority of the sites were private single- or multiplefamily holdings (i.e., forestry cooperatives) ranging from $\sim 10$ to 200 ha in size; six of these were primarily managed for maple syrup production ("sugarbushes") or were being converted into sugarbushes. Five of the 35 sites were current or former industrial timberlands, up to 710 ha in size. Six sites were publically owned (e.g., state forests), several of which were over 12000 ha in size and one of which was being converted to a sugarbush. Eleven sites held American Tree Farm, Forest Stewardship Council, Northeast Organic Farming Association, and/or Vermont Family Forests certifications, all promoting a degree of sustainable management practices but with widely varying standards.

\section{Sampling protocol and variables measured}

At each of the 35 sites, areas within the harvested stand were paired with adjoining unharvested areas of the same or closely matching stand; the latter areas were used as comparative references. Thus, each geographic site had two ecologically comparable areas that were sampled (hereafter termed "harvested" and "reference" areas). We recognize the limitations inherent in this approach, in that we did not quantify true pre- to postharvest changes. However, by standardizing values with a "percentage difference" metric comparing harvested to reference areas (see Data processing, below), together with a reasonably robust sample size, our approach provides sufficient support from which to draw inferences about harvesting impacts.

Overstory composition and structure were inventoried at 4-7 (number proportionate to stand area) randomly placed variable-radius prism plots (2.3 metric basal-area factor) well distributed throughout each site. Species and diameter at breast height $(\mathrm{dbh} ; 1.37 \mathrm{~m})$ of all live trees and snags $>5 \mathrm{~cm}$ dbh were recorded within each of these plots. Snag decay stage (1-9) was recorded following Sollins et al. (1987). Snag heights were measured using an Impulse 200 laser range finder (Laser Technology, Englewood, Colorado, USA). 


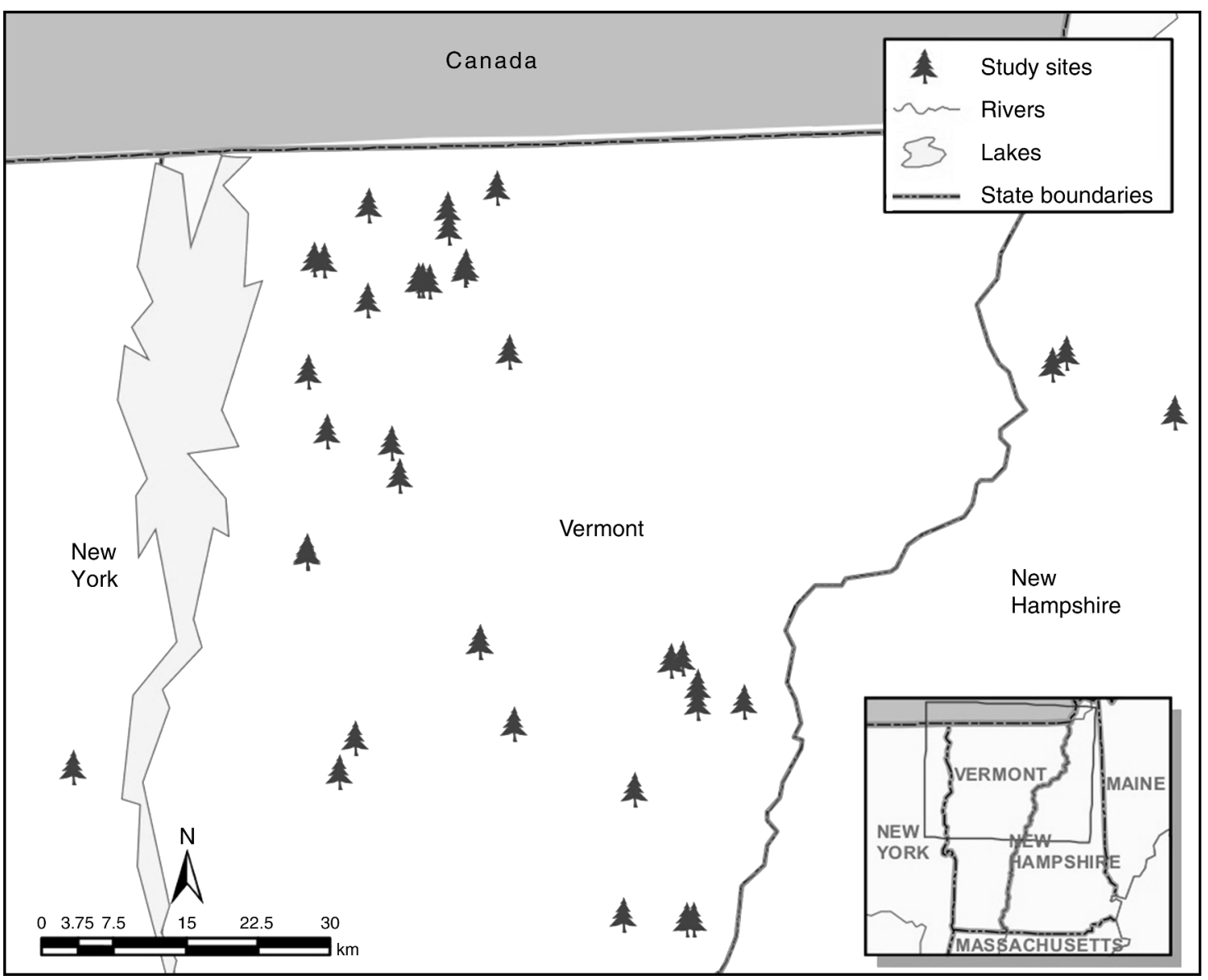

FIG. 1. Map of the study area and 35 individual study sites in the northeastern United States.

Downed woody debris was measured using the lineintercept method (Van Wagner 1968). Downed coarse woody debris (DCWD) $\geq 10 \mathrm{~cm}$ in diameter at intercept and $\geq 1 \mathrm{~m}$ in length was sampled along a randomly oriented transect of $35.7 \mathrm{~m}$ centered on the middle of each overstory plot, following protocol described in Shiver and Borders (1996) and Woodall and Williams (2005). The decay stage of each piece of DCWD was recorded using a $1-5$ classification system (Sollins et al. 1987). Fine woody debris (FWD) $\geq 2 \mathrm{~cm}$ in diameter at intercept and $\geq 10 \mathrm{~cm}$ in length was sampled along a central 25.2-m subsection of each line-intercept transect, following protocol described in Woodall and Williams (2005), which requires measurement of the diameter at intercept and debris lean angle.

To inventory downed tree crowns, both naturally occurring (e.g., wind thrown) and those left on the forest floor post-harvest, we established circular 0.1-ha plots centered on the same coordinates as the variable-radius prism plots. Within these, we tallied all downed tree crowns, recorded each crown's largest diameter within the plot, and determined whether it was felled or caused by natural disturbance and/or mortality. We sampled any tree crown $\geq 3 \mathrm{~m}$ in length, $\geq 10 \mathrm{~cm}$ in diameter, and with three limbs at least $1 \mathrm{~m}$ long within the plot (see Littlefield 2011).

\section{Data processing}

To calculate stand-structure metrics we input field data into either Microsoft Excel spreadsheets or the Northeast Ecosystem Management Decision Model (NED-2; Twery et al. 2005). Live-tree aboveground biomass estimates were generated from species-group specific allometric equations in Jenkins et al. (2003). Volumes of DCWD and FWD were calculated using volume-estimator equations developed by Van Wagner (1968) and described in Shiver and Borders (1996) and Woodall and Williams (2005). To characterize some aspects of aggregate stand structural complexity, the Shannon-Weiner diversity index $(H)$ was applied to "pseudo-species" using proportions of basal area by species and size class (in 5-cm intervals). The $H$ index was calculated for each stand using the formula

$$
H=-\sum p_{i} \ln p_{i}
$$

where $p_{i}$ is the proportion of basal area per pseudospecies (Staudhammer and LeMay 2001, Leniere and Houle 2006). Relatively lower values indicate a more 
homogenous forest structure with regards to both species composition and size distribution (Leniere and Houle 2006).

The percentage difference between harvested and reference values was calculated for each structural variable at each site, using the formula

Percentage difference $=\left(V_{\mathrm{H}}-V_{\mathrm{R}}\right) /\left(\left(V_{\mathrm{H}}+V_{\mathrm{R}}\right) / 2\right) \times 100$

where $V$ is the variable of interest. Without assuming the data to be from a controlled, before-and-after experiment, this percentage-difference metric, modified from Westerling et al. (2006), allows for standardized comparisons by normalizing the relative difference between harvested and reference values across the range of inherent site variability.

To determine the proportion of harvested volume used for bioenergy applications, we estimated the percentage of harvested volume allocated to different product streams and bioenergy application based on volumes and masses by product/application tabulated at landings or from mill/end-user receipts. Mass-to-volume conversion factors from Ashley (1999) were used, weighted by each site's relative species composition (basal area by species). We used a conversion factor of 0.96 cords $/ \mathrm{mbf}$ (thousand board feet), i.e., 0.41 cords $/ \mathrm{m}^{3}$ (Ashley 1999).

\section{Data analysis}

Departure from normality was tested $(\alpha=0.05)$ for all variables using the Shapiro-Wilk test (McGarigal et al. 2000). These tests revealed statistically significant departures for some variables, so we employed only nonparametric tests in our data analysis. Variances were not pooled when they proved nonhomogenous $(\alpha=0.05)$ as determined by Levene's test of homogeneity of variance (McGarigal et al. 2000). For most statistical tests, sites and associated variables were grouped in two categories: (1) whole-tree harvested (hereafter "WTH") and (2) non-whole-tree harvested (hereafter "nonWTH"). To better elucidate the relationship between bioenergy harvesting and structural indicators, we further divided the sites into those with and those without bioenergy allocation (noted below where applicable).

Our statistical analysis was conducted in five steps and performed using JMP 9 (SAS Institute 2011) and S-Plus 8.2 (TIBCO 2010) software. First, paired means between harvested and reference values at each site were compared using the Wilcoxon signed-rank test (hereafter "Comparison Method A"). Second, percentage differences of structural variables between harvested and reference areas at each site (hereafter "harvestinduced contrast" or "contrast") were compared across sites using the Mann-Whitney $U$ test (hereafter "Comparison Method B"; we used the Kruskal-Wallis oneway ANOVA test when grouping sites into three categories). Third, diameter-class distributions were compared using the Kolmogorov-Smirnov two-sample goodness-of-fit test and Wilcoxon signed-rank test. Fourth, select percentage differences that were normally distributed were regressed by the percentage of harvested volume allocated to bioenergy.

Last, multivariate classification and regression tree (CART) analysis (Breiman et al. 1984) was used (S-Plus 8.2 software) to determine the variables that best predict post-harvest impacts. For this analysis we focused on DCWD due to its particular importance in habitat functions and the attention it has received in bioenergy harvesting guidelines. We also used the $H$ index as a dependent variable to examine predictors of postharvest structural complexity more generally. CART is a robust, nonparametric technique that is increasingly employed in ecological studies worldwide (e.g., De'ath and Fabricius 2000, Keeton et al. 2007, Nunery and Keeton 2010). By repeatedly splitting the values of a dependent variable into more homogenous groups using combinations of either categorical or numeric explanatory variables, a tree can explain both the variation within a single dependent variable and the hierarchically ranked predictive power of multiple independent variables (De'ath and Fabricius 2000). In our analyses costcomplexity pruning was used to eliminate nonsignificant nodes.

\section{RESUlts}

\section{Whole-tree harvests vs. non-whole-tree harvests}

Comparisons using structural indicators strongly supported the first hypothesis that whole-tree harvesting has a more significant impact on stand structural elements than does non-whole-tree harvesting. In our paired Comparison Method A, reference areas at WTH (whole-tree harvest) sites had significantly greater values for all stocking metrics than harvested areas at WTH sites $(P<0.05$; Table 2; Fig. 2); reference areas at nonWTH sites had significantly greater values for all stocking metrics $(P<0.05)$ except standing snag density and large $(>50 \mathrm{~cm} \mathrm{dbh})$ live-tree density.

Reference areas at WTH sites had significantly greater volumes of well-decayed (stages 3-5) downed coarse woody debris (DCWD; $P<0.05$ ) and significantly greater $H$ index values $(P<0.0001)$ compared to harvested areas at WTH sites. Comparisons at nonWTH sites did not demonstrate significant differences for these two metrics. Reference areas at non-WTH sites had significantly greater $q$ factor values (the ratio of the number of trees in each size class to the number of trees in each successively larger size class; $P<0.05)$ and significantly lower volumes of early decay stage (1-2) DCWD $(P<0.05)$ compared to harvested areas at nonWTH sites. Comparisons at WTH sites did not demonstrate significant differences for these two metrics. Harvested areas at both WTH and non-WTH sites had significantly greater FWD volumes $(P<0.05)$ and total 
TABLE 2. Descriptive statistics and Wilcoxon signed-rank (matched pair) results contrasting harvested (Harv.) and reference (Ref.) areas within whole-tree harvested (WTH) sites and non-WTH sites (Comparison Method A).

\begin{tabular}{|c|c|c|c|c|c|}
\hline \multirow[b]{4}{*}{ Forest-structure variable } & \multicolumn{5}{|c|}{ Comparison Method A } \\
\hline & \multirow[b]{3}{*}{ Harv. mean } & \multirow[b]{3}{*}{ Ref. mean } & \multicolumn{3}{|l|}{ Whole-tree harvests } \\
\hline & & & \multirow[b]{2}{*}{ Diff. (mean $\pm \mathrm{SE})$} & \multicolumn{2}{|c|}{ Wilcoxon signed-rank } \\
\hline & & & & $S_{24}$ & $P$ \\
\hline \multicolumn{6}{|l|}{ Stocking (live and dead) } \\
\hline Live net cubic volume $\left(\mathrm{m}^{3} / \mathrm{ha}\right)$ & 83.72 & 126.94 & $-43.22 \pm 4.75$ & 162.50 & $<0.0001$ \\
\hline \multicolumn{6}{|l|}{ Basal area $\left(\mathrm{m}^{2} / \mathrm{ha}\right)$} \\
\hline $\begin{array}{l}\text { Total } \\
\text { Live } \\
\text { Dead }\end{array}$ & $\begin{array}{r}19.50 \\
17.69 \\
1.82\end{array}$ & $\begin{array}{r}30.14 \\
27.14 \\
3.00\end{array}$ & $\begin{array}{l}-10.64 \pm 1.09 \\
-9.45 \pm 1.06 \\
-1.18 \pm 0.4\end{array}$ & $\begin{array}{l}162.50 \\
162.50 \\
107.50\end{array}$ & $\begin{array}{r}<\mathbf{0 . 0 0 0 1} \\
<\mathbf{0 . 0 0 0 1} \\
\mathbf{0 . 0 0 1 9}\end{array}$ \\
\hline Abg. live biomass $(\mathrm{Mg} / \mathrm{ha})$ & 113.36 & 173.24 & $-59.88 \pm 5.96$ & 162.50 & $<\mathbf{0 . 0 0 0 1}$ \\
\hline \multicolumn{6}{|l|}{ Stem density (no./ha) } \\
\hline $\begin{array}{l}\text { Total } \\
\text { Live } \\
\text { Dead }\end{array}$ & $\begin{array}{r}638.53 \\
583.33 \\
55.20\end{array}$ & $\begin{array}{r}1064.51 \\
957.72 \\
106.79\end{array}$ & $\begin{array}{r}-425.98 \pm 86.23 \\
-374.39 \pm 79.06 \\
-51.59 \pm 23.19\end{array}$ & $\begin{array}{r}145.50 \\
139.50 \\
79.50\end{array}$ & $\begin{array}{r}<\mathbf{0 . 0 0 0 1} \\
<\mathbf{0 . 0 0 0 1} \\
\mathbf{0 . 0 2 9 2}\end{array}$ \\
\hline Large live-tree density (no./ha) $\dagger$ & 8.87 & 22.95 & $-14.08 \pm 8.87$ & 96.50 & 0.0001 \\
\hline $\begin{array}{l}\text { Tree diameter distributions } \\
q \text { factor } \$ \\
\text { Quadratic mean diameter }(\mathrm{cm}) \S \\
\text { Average dbh }(\mathrm{cm})\end{array}$ & $\begin{array}{r}1.20 \\
21.19 \\
18.74\end{array}$ & $\begin{array}{r}1.22 \\
19.85 \\
17.01\end{array}$ & $\begin{array}{r}-0.02 \pm 0.01 \\
1.34 \pm 0.93 \\
1.73 \pm 1.08\end{array}$ & $\begin{array}{r}29.50 \\
-46.50 \\
-47.00\end{array}$ & $\begin{array}{l}0.3791 \\
0.2176 \\
0.2125\end{array}$ \\
\hline \multicolumn{5}{|l|}{ Downed wood } & 0.0108 \\
\hline $\begin{array}{l}\text { CWD volume }\left(\mathrm{m}^{3} / \mathrm{ha}\right) \\
\text { Decay stages } 1-2 \\
\text { Decay stages } 3-5 \\
\text { Total }\end{array}$ & $\begin{array}{l}16.67 \\
23.70 \\
40.37\end{array}$ & $\begin{array}{l}12.68 \\
36.00 \\
48.69\end{array}$ & $\begin{aligned} 3.99 & \pm 2.88 \\
-12.3 & \pm 5.2 \\
-8.32 & \pm 5.66\end{aligned}$ & $\begin{array}{r}-48.50 \\
88.50 \\
60.50\end{array}$ & $\begin{array}{l}0.1978 \\
\mathbf{0 . 0 1 3 9} \\
0.1046\end{array}$ \\
\hline $\begin{array}{l}\text { Total downed-crown density (no./ha) } \\
\text { Psuedo-species structural diversity index }\end{array}$ & $\begin{array}{r}84.41 \\
2.80\end{array}$ & $\begin{array}{r}64.72 \\
3.14\end{array}$ & $\begin{array}{r}19.69 \pm 8.11 \\
-0.34 \pm 0.06\end{array}$ & $\begin{array}{r}-93.50 \\
146.50\end{array}$ & $\begin{array}{r}0.0088 \\
<0.0001\end{array}$ \\
\hline
\end{tabular}

Note: Boldface is used to highlight significant $P$ values $(P<0.05)$.

$\dagger$ Large trees are those $>50 \mathrm{~cm}$ dbh.

$\$$ The $q$ factor is the ratio of the number of trees in each size class to the number of trees in each successively larger size class. $\S$ Quadratic mean diameter is the diameter of the tree of average basal area.

- Total crown density includes both naturally downed and felled crowns.

downed crown densities (including felled and naturally downed crowns; $P<0.05$ ) compared to reference areas.

In our non-paired Comparison Method B, non-WTH sites had a significantly greater harvest-induced contrast (i.e., percentage difference) in downed-crown densities than WTH sites $(P<0.05$; Table 3; Fig. 2). When we further subdivided non-WTH sites, non-WTH sites without bioenergy had significantly greater downedcrown densities than non-WTH sites with bioenergy generation, which in turn had significantly greater downed-crown densities than WTH sites (KruskalWallis one-way ANOVA, $K=18.43 ; P<0.0001$; Bonferroni correction of $\alpha=0.05 / 3)$. Harvested areas averaged 142 felled crowns/ha at non-WTH sites without bioenergy, 72 felled crowns/ha at non-WTH sites with bioenergy, and 27 felled crowns/ha at WTH sites.

It is likely that the directions and magnitudes of the contrasts (i.e., percentage differences) comparing harvested to reference areas for many of the structural metrics indeed represent meaningful differences between WTH and non-WTH sites, though these relationships did not emerge from nonparametric comparisons as being statistically significant ( $\alpha=0.05$; Tables 2 and 3 ). The lack of statistical significance is attributable to the high degree of variability in the data set, which in turn relates to the spatial complexity of the stands (e.g., patch structure) and spatial heterogeneity in harvesting effects. However, in absolute numbers the positive contrasts in FWD volume and early decay stage DCWD volume at non-WTH sites were nearly twice as great as at WTH sites. The negative contrast in well-decayed DCWD volume at WTH sites was over 16 times greater in magnitude than at non-WTH sites. Non-WTH sites exhibited a positive contrast in total DCWD volume while WTH sites exhibited a negative contrast.

\section{Diameter distributions}

The aforementioned variability in the data set may further explain why there were no statistically significant differences (Kolmogorov-Smirnov two-sample goodness-of-fit test; $P<0.05)$ in post-harvest diameter-class distributions between WTH $(n=25)$ and non-WTH $(n=$ 
TABle 2. Extended.

\begin{tabular}{|c|c|c|c|c|}
\hline \multicolumn{5}{|c|}{ Comparison Method A } \\
\hline \multicolumn{5}{|c|}{ Non-whole-tree harvests } \\
\hline \multirow[b]{2}{*}{ Harv. mean } & \multirow[b]{2}{*}{ Ref. mean } & \multirow[b]{2}{*}{ Diff. (mean $\pm \mathrm{SE}$ ) } & \multicolumn{2}{|c|}{ Wilcoxon signed-rank } \\
\hline & & & $S_{9}$ & $P$ \\
\hline 115.15 & 162.09 & $-46.94 \pm 10.74$ & 27.50 & 0.0020 \\
\hline $\begin{array}{r}25.08 \\
23.09 \\
1.99\end{array}$ & $\begin{array}{r}36.48 \\
32.78 \\
3.70\end{array}$ & $\begin{array}{l}-11.4 \pm 1.86 \\
-9.69 \pm 1.83 \\
-1.71 \pm 0.62\end{array}$ & $\begin{array}{l}27.50 \\
27.50 \\
21.00\end{array}$ & $\begin{array}{l}\mathbf{0 . 0 0 2 0} \\
\mathbf{0 . 0 0 2 0} \\
\mathbf{0 . 0 2 9 3}\end{array}$ \\
\hline 153.59 & 207.65 & $-54.06 \pm 12.22$ & 27.50 & 0.0020 \\
\hline $\begin{array}{r}755.09 \\
672.09 \\
83.00\end{array}$ & $\begin{array}{r}1095.92 \\
964.54 \\
131.38\end{array}$ & $\begin{array}{r}-340.83 \pm 81 \\
-292.45 \pm 81.01 \\
-48.38 \pm 55.44\end{array}$ & $\begin{array}{l}25.50 \\
23.50 \\
14.50\end{array}$ & $\begin{array}{l}\mathbf{0 . 0 0 5 9} \\
\mathbf{0 . 0 1 3 7} \\
0.1602\end{array}$ \\
\hline 35.24 & 42.26 & $-7.02 \pm 11.72$ & 6.50 & 0.5566 \\
\hline $\begin{array}{r}1.20 \\
21.58 \\
18.46\end{array}$ & $\begin{array}{r}1.24 \\
21.21 \\
18.22\end{array}$ & $\begin{array}{r}-0.04 \pm 0.01 \\
0.37 \pm 1.32 \\
0.24 \pm 1.48\end{array}$ & $\begin{array}{r}21.50 \\
-7.50 \\
-7.50\end{array}$ & $\begin{array}{l}\mathbf{0 . 0 2 7 3} \\
0.4922 \\
0.4922\end{array}$ \\
\hline 14.65 & 7.52 & $7.13 \pm 1.36$ & -21.50 & 0.0078 \\
\hline $\begin{array}{l}20.24 \\
39.21 \\
59.46\end{array}$ & $\begin{array}{r}7.63 \\
39.85 \\
47.48\end{array}$ & $\begin{aligned} 12.61 & \pm 5.46 \\
-0.64 & \pm 10.47 \\
11.98 & \pm 13.14\end{aligned}$ & $\begin{array}{r}-20.50 \\
3.50 \\
-8.50\end{array}$ & $\begin{array}{l}\mathbf{0 . 0 3 7 1} \\
0.7695 \\
0.4316\end{array}$ \\
\hline $\begin{array}{r}179.32 \\
3.16\end{array}$ & $\begin{array}{r}61.24 \\
3.33\end{array}$ & $\begin{aligned} 118.08 & \pm 14.6 \\
-0.17 & \pm 0.1\end{aligned}$ & $\begin{array}{r}-27.50 \\
15.50\end{array}$ & $\begin{array}{l}\mathbf{0 . 0 0 2 0} \\
0.1309\end{array}$ \\
\hline
\end{tabular}

10) sites, or, alternatively categorized, between bioenergy sites $(n=29)$ and non-bioenergy sites ( $n=6$; Fig. 3$)$. The density of live-trees, however, was greater in the majority of diameter classes for non-WTH sites than WTH sites (paired Wilcoxon signed-rank test; $P=0.03$ ); there was no significant difference in live-tree density between bioenergy and non-bioenergy sites $(P<0.05)$.

\section{Relating bioenergy volume and structural indicators}

In an analysis employing all of our sites and using continuous variables, no significant correlation $(\alpha=$ 0.05 ) emerged between the percentage of harvested volume allocated to bioenergy and measures of harvesting impact (i.e., harvest-induced contrasts in structural metrics; Fig. 4). This held for percentage difference in live-tree aboveground biomass; percentage difference in $H$ index; percentage difference in snag density; and all other variables tested (i.e., those with percentage differences that were normally distributed; Tables 2 and 3). Thus, the regressions did not signal a clear relationship between post-harvest structural condition and the proportion of product allocated to bioenergy. A majority $(n=25)$ of our sites demonstrated a negative percentage difference in snag density although a positive percentage difference was observed at other sites.

\section{Influence of site- and harvest-specific factors on post-harvest structure}

The results of classification and regression tree (CART) analyses largely supported the second hypothesis that measures of harvest intensity best predict postharvest stand structure (Fig. 5). However, the percentage of harvested volume allocated to bioenergy did not consistently emerge as a primary predictor in structural element harvest-induced contrasts. Rather, it was the specific silvicultural treatments that best predicted outcomes, suggesting that volume allocated to bioenergy is only one of several harvesting considerations affecting stand structure.

Of the 14 independent variables (Table 4) included in the initial model analysis specifying DCWD volume as the dependent variable, five were incorporated into the final CART model (Fig. 5): harvest treatment, type of skidder used, land ownership, percentage of harvested volume to bioenergy, and land certification (reflecting various standards of sustainable management practices). Harvest treatment was the strongest predictor of the 

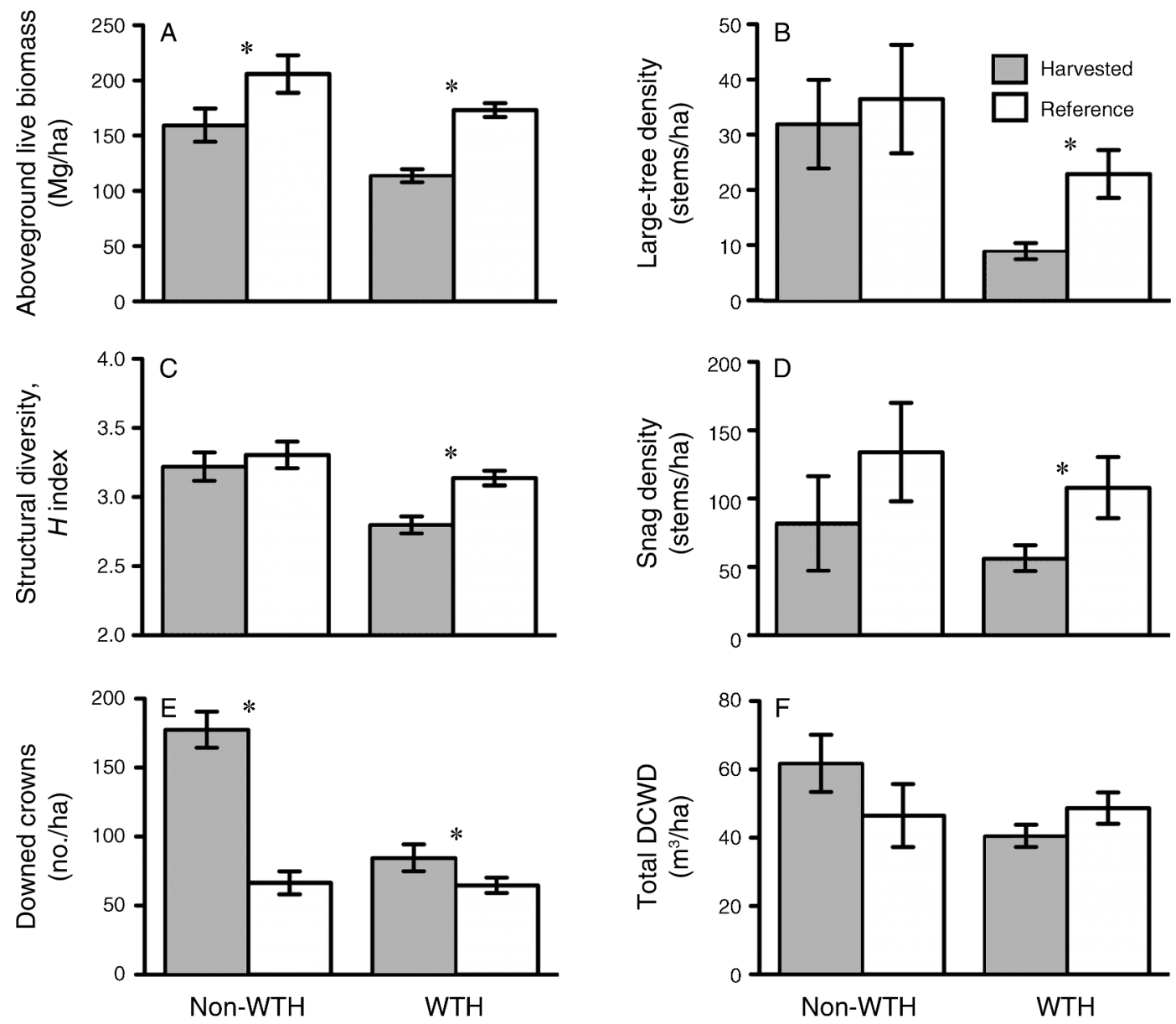

FIG. 2. Plots of values for structural characteristics by site-treatment groupings: whole-tree harvested (WTH) sites, $n=25$ sites; non-WTH sites, $n=10$ sites). (A) Live-tree aboveground biomass. (B) Density of large trees (trees $>50 \mathrm{~cm} \mathrm{dbh}$ ). (C) Structural diversity $(H)$ index (no associated units). (D) Standing-snag density. (E) Total felled and naturally downed crown density. (F) Volume of downed coarse woody debris (DCWD), including all decay stages. Data are means \pm SE; asterisks denote significant differences $(P<0.05)$. Refer to Tables 2 and 3 for values and comparison outcomes.

harvest-induced contrast in total DCWD volume (Fig. $5 \mathrm{~A})$; the primary split at the root node was divided between (left side) crop tree release, single-tree selection, and single-tree/small-group combinations and (right side) group selection, thinning from below, and shelterwood.

The left side of the tree (Fig. 5A) was further divided by type of skidder used: sites within this partitioning of treatments at which only a cable skidder was used $(n=7$ sites) had a less negative contrast in total DCWD volume than did sites at which only a grapple skidder was used $(n=10)$. Of the latter sites, those from which more than $61.5 \%$ of the harvested volume went to bioenergy $(n=5)$ exhibited a more negative contrast in total DCWD volume than those sites from which less than $61.5 \%$ of the harvest volume went to bioenergy $(n=$ $5)$.

The right side of the Fig. 5A tree (group selection, thinning from below, and shelterwood sites) was further divided by land ownership, which explains a consider- able amount of the dependent-variable deviance on this side of the tree (reflected in the length of the vertical segments below the ownership split). State-owned sites and timberlands currently or recently under industrial ownership $(n=7)$ exhibited negative harvest-induced contrasts (i.e., less DCWD post-harvest), whereas single-family or cooperatively owned sites $(n=11)$ had positive harvest-induced contrasts (i.e., more DCWD post-harvest). Of the latter sites, those that were not certified $(n=5)$ exhibited a greater contrast in total DCWD volume than did certified sites $(n=6)$.

The second CART model was consistent with the first: harvest treatment was the strongest predictor of the harvest-induced contrast in aggregate structural complexity as measured by the Shannon-Wiener diversity index, $H$ (Fig. 5B). The primary split at the root node was divided between (left side) group selection and shelterwood and (right side) the remainder of the treatments. Of these latter treatments, the sites from which no chips were generated or from which chips went 
TABLE 3. Comparison Method B: Mann-Whitney $U$ results comparing percentage differences in forest-structure variables for whole-tree harvest (WTH) sites cf. non-WTH sites.

\begin{tabular}{|c|c|c|c|c|}
\hline \multirow[b]{3}{*}{ Forest-structure variable } & \multicolumn{4}{|c|}{ Percentage difference whole-tree harvests (WTH) cf. percentage difference non-WTH } \\
\hline & \multirow{2}{*}{$\begin{array}{l}\text { WTH } \\
\text { \% diff. mean }\end{array}$} & \multirow{2}{*}{$\begin{array}{l}\text { Non-WTH } \\
\% \text { diff. mean }\end{array}$} & \multicolumn{2}{|c|}{ Mann-Whitney } \\
\hline & & & $U$ & $P$ \\
\hline Stocking (live and dead) & & & & \\
\hline $\begin{array}{l}\text { Live net cubic volume }\left(\mathrm{m}^{3} / \mathrm{ha}\right) \\
\text { Basal area }\left(\mathrm{m}^{2} / \mathrm{ha}\right)\end{array}$ & $-42.22 \%$ & $-34.50 \%$ & 98.00 & 0.3332 \\
\hline $\begin{array}{l}\text { Total } \\
\text { Live } \\
\text { Dead }\end{array}$ & $\begin{array}{l}-43.80 \% \\
-43.20 \% \\
-52.81 \%\end{array}$ & $\begin{array}{l}-37.72 \% \\
-34.56 \% \\
-62.63 \%\end{array}$ & $\begin{array}{r}107.00 \\
99.00 \\
111.00\end{array}$ & $\begin{array}{l}0.5288 \\
0.3518 \\
0.6220\end{array}$ \\
\hline $\begin{array}{l}\text { Abg. live biomass }(\mathrm{Mg} / \mathrm{ha}) \\
\text { Stem density (no./ha) }\end{array}$ & $-43.41 \%$ & $-30.25 \%$ & 84.00 & 0.1392 \\
\hline $\begin{array}{l}\text { Total } \\
\text { Live } \\
\text { Dead }\end{array}$ & $\begin{array}{l}-52.10 \% \\
-50.97 \% \\
-49.32 \%\end{array}$ & $\begin{array}{l}-36.98 \% \\
-36.51 \% \\
-57.97 \%\end{array}$ & $\begin{array}{r}99.00 \\
109.00 \\
117.00\end{array}$ & $\begin{array}{l}0.3518 \\
0.5714 \\
0.7841\end{array}$ \\
\hline $\begin{array}{l}\text { Large live-tree density (no./ha) } \dagger \\
\text { Tree diameter distributions }\end{array}$ & $-69.53 \%$ & $-12.80 \%$ & 86.00 & 0.1578 \\
\hline $\begin{array}{l}q \text { factor } \ddagger \\
\text { Quadratic mean diameter }(\mathrm{cm}) \S \\
\text { Average dbh }(\mathrm{cm})\end{array}$ & $\begin{array}{r}-1.08 \% \\
5.42 \% \\
8.02 \%\end{array}$ & $\begin{array}{r}-2.66 \% \\
1.09 \% \\
0.52 \%\end{array}$ & $\begin{array}{r}84.50 \\
122.00 \\
117.00\end{array}$ & $\begin{array}{l}0.1440 \\
0.9273 \\
0.7842\end{array}$ \\
\hline $\begin{array}{l}\text { Downed wood } \\
\text { FWD volume }\left(\mathrm{m}^{3} / \mathrm{ha}\right)\end{array}$ & $35.44 \%$ & $62.77 \%$ & 58.00 & 0.1841 \\
\hline $\begin{array}{l}\text { CWD volume }\left(\mathrm{m}^{3} / \mathrm{ha}\right) \\
\text { Decay stages } 1-2 \\
\text { Decay stages } 3-5 \\
\text { Total }\end{array}$ & $\begin{array}{r}34.77 \% \\
-30.32 \% \\
-16.47 \%\end{array}$ & $\begin{array}{r}71.71 \% \\
-1.80 \% \\
28.08 \%\end{array}$ & $\begin{array}{r}97.50 \\
111.00 \\
92.00\end{array}$ & $\begin{array}{l}0.3242 \\
0.6220 \\
0.2353\end{array}$ \\
\hline $\begin{array}{l}\text { Total downed-crown density (no./ha) } \\
\text { Psuedo-species structural diversity index }\end{array}$ & $\begin{array}{r}16.76 \% \\
-11.64 \%\end{array}$ & $\begin{array}{r}97.85 \% \\
-5.14 \%\end{array}$ & $\begin{array}{l}23.00 \\
75.00\end{array}$ & $\begin{array}{l}\mathbf{0 . 0 0 0 2} \\
0.0707\end{array}$ \\
\hline
\end{tabular}

Note: Boldface is used to highlight significant $P$ values $(P<0.05)$.

$\uparrow$ Large trees are those $>50 \mathrm{~cm}$ dbh.

\$ The $\mathrm{q}$ factor is the ratio of the number of trees in each size class to the number of trees in each successively larger size class.

$\S$ Quadratic mean diameter is the diameter of the tree of average basal area.

- Total crown density includes both naturally downed and felled crowns.

to a combination of municipal and school end users $(n=$ 8 sites) had the least contrast in $H$ index values. Of the sites (right side of the tree) from which all chips generated went to municipal bioenergy use (i.e., a power plant), those that were either crop tree releases or thinnings from below and that employed a grapple skidder $(n=6)$ exhibited the greatest negative contrast in $H$ index values.

\section{DISCUSSION}

The stand-structure impacts of bioenergy harvesting are highly variable based on our results. While some bioenergy harvests led to reduced representation of ecologically important stand structural elements compared to non-bioenergy harvests, others exhibited little or no impact. Taken in aggregate, our results indicate that a complex interaction of site- and harvest-specific factors determine impacts on stand structure. We recognize our results reflect short-term effects; some of these may dissipate over time as stand structure recovers. There may be cumulative effects at landscape scales, however, from short-term impairments spread across multiple stands, leading to reduced representation of some structural attributes.
Two patterns are particularly apparent and support the research hypotheses. First, whole-tree harvesting results in significantly reduced representation of certain stand structural elements (e.g., snag density) compared to non-whole-tree harvesting. Second, measures of harvest intensity (e.g., harvest treatment) emerge as the best predictors of certain post-harvest structural conditions, although the percentage of harvested volume allocated to bioenergy does not predict post-harvest structure. The latter suggests that material is harvested for bioenergy as part of operations that encompass a range of stand conditions, silvicultural objectives and practices, economic constraints, and product streams. These considerations, rather than percentage of harvested volume allocated to bioenergy per se, are the primary drivers of structural impacts in many cases.

\section{Whole-tree harvests vs. non-whole-tree harvests}

Standing live and dead trees.- Harvested areas of whole-tree harvested (WTH) sites had significantly fewer large live trees $(>50 \mathrm{~cm} \mathrm{dbh})$ and standing snags than did paired reference areas, a pattern that did not hold for non-WTH sites. This finding is consistent with recent investigations addressing snag reduction at whole-tree 

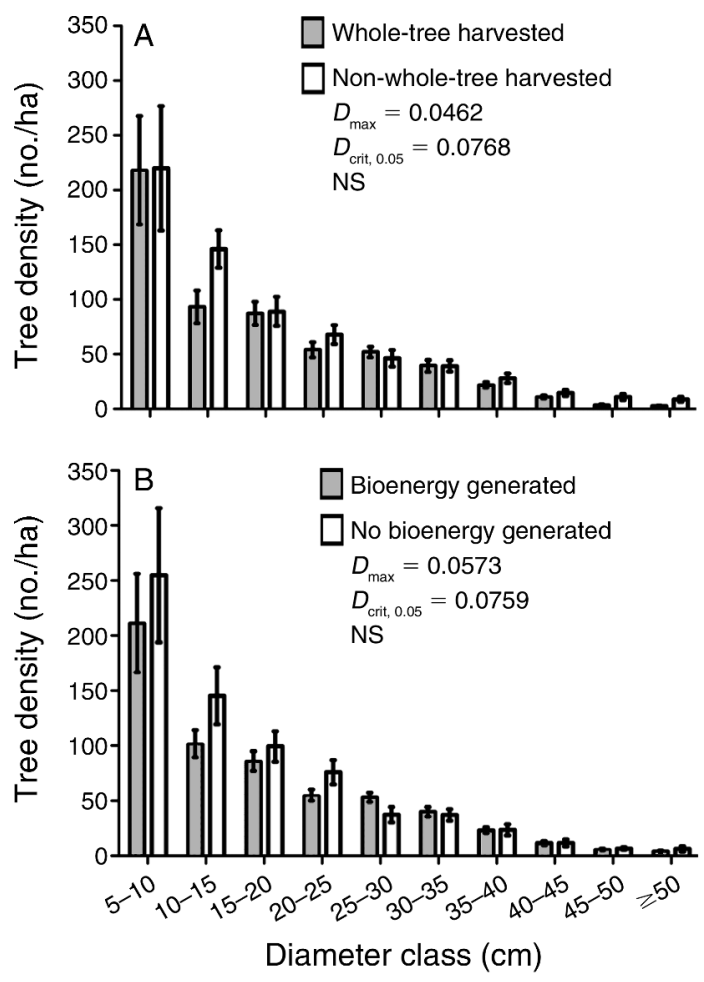

FIG. 3. Post-harvest live-tree diameter distributions (mean $\pm \mathrm{SE})$ of all sites $(n=35)$ grouped by (A) harvest type and (B) whether a portion of the harvested volume went to bioenergy or not. Twenty-five sites were whole-tree harvested, ten were not. Twenty-nine sites had a portion of the harvested volume allocated to bioenergy, six did not. Diameter distributions were compared by the Kolmogorov-Smirnov two-sample goodnessof-fit test; there were no statistically significant differences.

harvested bioenergy sites (Briedis et al. 2011). The removal of large trees may impair the future availability and attributes of snags and downed coarse woody debris (DCWD; Angers et al. 2005), further exacerbating the impact upon snags and DCWD volumes witnessed herein. Thus, habitat availability and quality associated with large trees and snags - in addition to DCWD recruitment-may be impaired if bioenergy harvest operators target larger stems of poor timber quality without some level of deliberate retention (Lattimore et al. 2009, Janowiak and Webster 2010). A minority (six) of the 25 WTH sites did not show large reductions in snag density, suggesting that some operators are not impacting standing dead trees.

Structural diversity (H) index.-Whole-tree harvesting had a greater, more negative impact on stand structural complexity, as measured by $H$ index values, than did other forms of harvesting. Relatively lower values indicate a more homogenous forest structure in terms of species composition and size distribution (Leniere and Houle 2006). Our results are consistent with the inference that bioenergy harvests are removing larger stems of poorer quality (Lattimore et al. 2009,
Janowiak and Webster 2010) or less profitable species. Six of the 25 WTH sites (only one non-WTH site) were sugarbush conversion cuts (a preparatory cut for maple sugar extraction). As such, deliberate retention of large sugar maples at wide, even spacing, would lead to a low $H$ index (Crow et al. 2002, Leniere and Houle 2006). Thus, when bioenergy harvests occur jointly with other specific structure and composition goals (e.g., sugarbush conversion, ladder-fuel reduction, and so forth), impacts must be considered in the context of multiple objectives.

Downed woody debris volumes.-The large, positive percentage differences in fine woody debris (FWD) volume and early decay stage DCWD at non-WTH sites and negative percentage difference in total DCWD volumes at WTH sites represent a large relative recruitment of dead woody material-or slash reten-
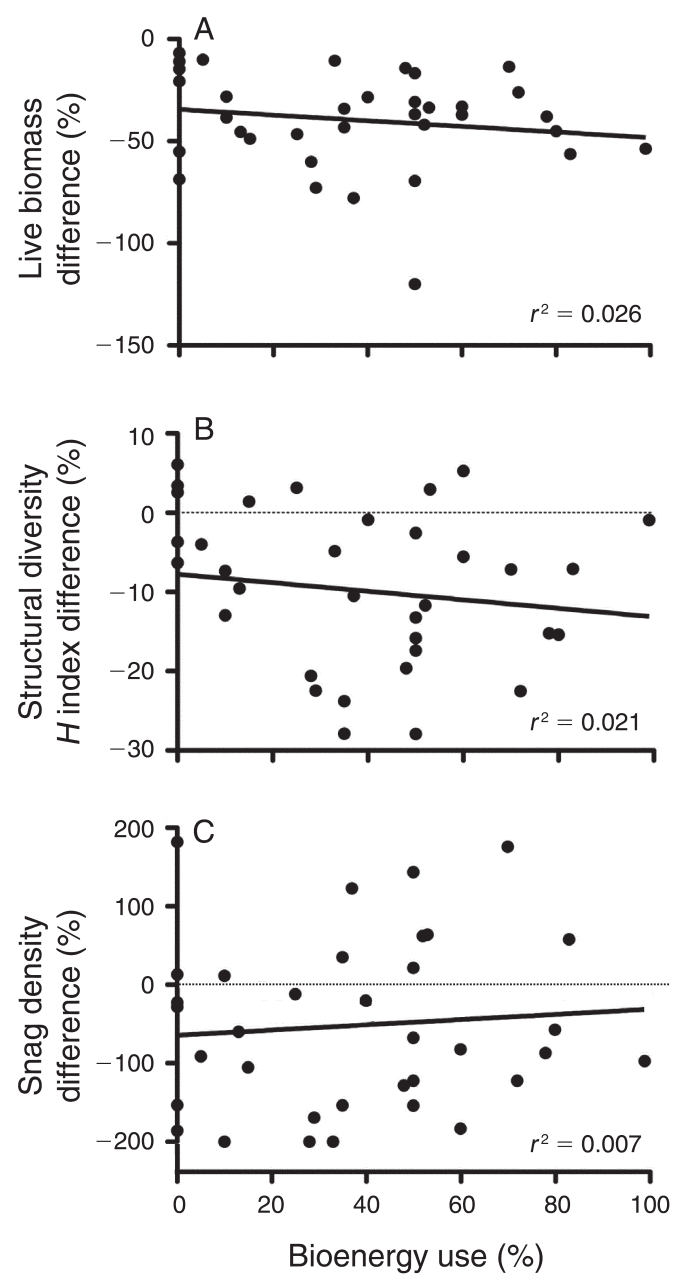

FIG. 4. The percentage difference in forest-structure variables (harvested values cf. reference values) regressed against the percentage of harvested volume used for bioenergy. (A) Regression of percentage difference in live-tree aboveground biomass; (B) regression of percentage difference in the structural diversity $H$ index; (C) regression of percentage difference in snag density. 


\section{A) DCWD volume}

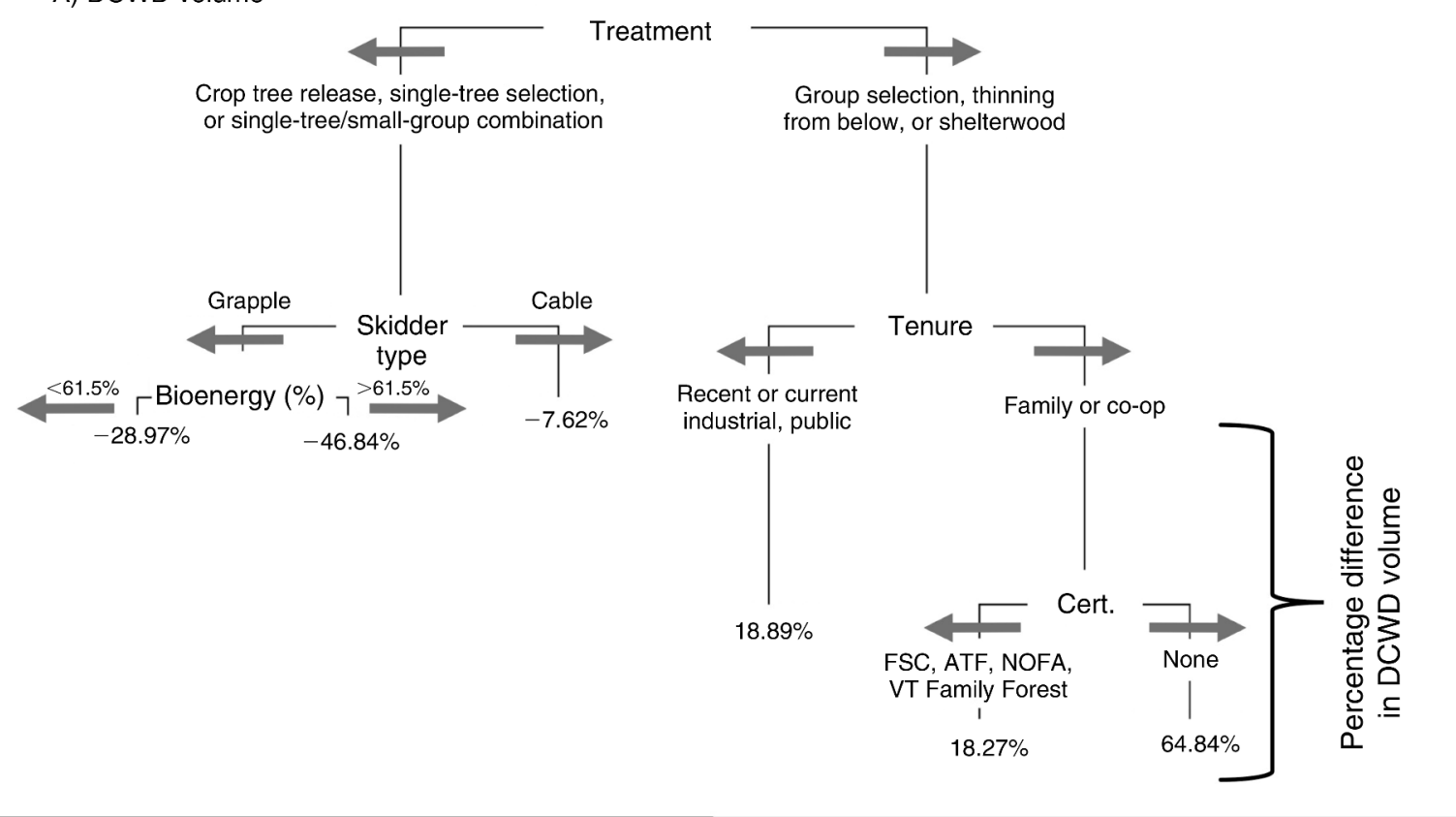

B) $H$ index

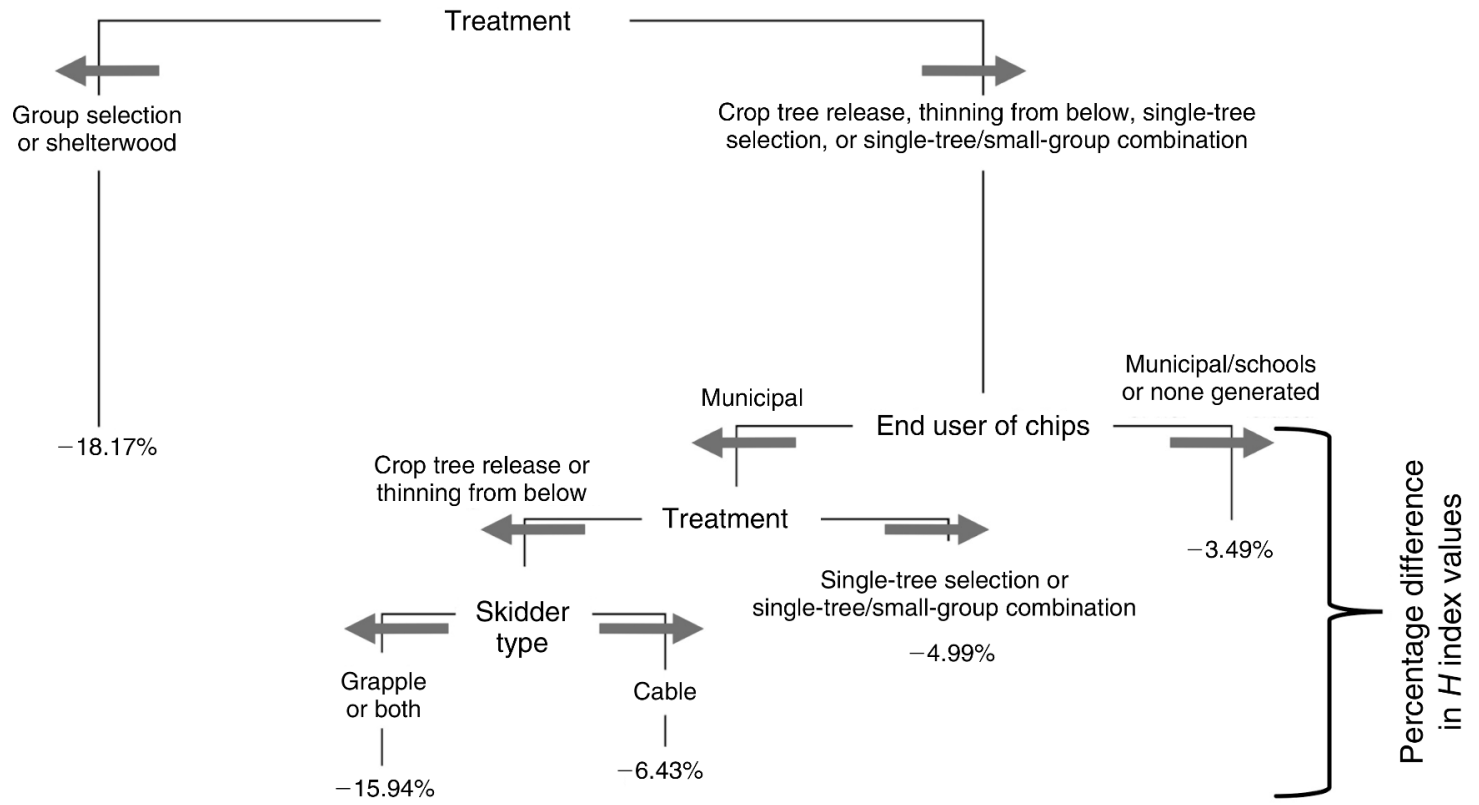

FIG. 5. Outputs of classification and regression tree (CART) analyses of the percentage difference in (A) downed coarse woody debris (DCWD) volume and (B) structural diversity $H$ index values comparing paired harvested and reference areas. The CART analysis ranks independent variables, top to bottom, by their predictive strength of the dependent variable (percentage difference in DCWD volume and $H$ index values; partitioned mean values are at terminal nodes). Independent variables in the CART analyses were selected from an initial set of 14 variables (see Table 3). The length of each vertical line segment is proportional to the amount of deviance explained by the preceding independent variable. The minimum deviance required for each split is 0.01 ; the minimum number of observations required for each split for percentage difference in DCWD volume is 5 ; the minimum number of observations required for each split for percentage difference in $H$ index values is 6. "Cert." refers to land certification conferred by third-party certifying organizations (FSC, Forest Stewardship Council; ATF, American Tree Farm; NOFA, Northeast Organic Farming Association; and/or Vermont (VT) Family Forests), whose standards, used to determine and certify use of sustainable management practices, vary widely from each other. 
TABLE 4. Potential predictor variables used in the classification and regression-tree (CART) analyses, their respective levels, and the number of sites (total $n=35$ sites) described by the variables.

\begin{tabular}{|c|c|c|}
\hline Variable $\uparrow$ & Levels & No. sites \\
\hline Land ownership & $\begin{array}{l}\text { private: family, family co-op, non-profit, small institution } \\
\text { private: recent or current industrial } \\
\text { public }\end{array}$ & $\begin{array}{r}26 \\
3 \\
6\end{array}$ \\
\hline \multirow{4}{*}{$\begin{array}{l}\text { Government incentive } \\
\text { program } \ddagger \\
\text { Easement }\end{array}$} & yes & 23 \\
\hline & no & 12 \\
\hline & yes & 6 \\
\hline & no & 29 \\
\hline \multirow[t]{2}{*}{ Certification§ } & yes & 11 \\
\hline & no & 24 \\
\hline \multirow{2}{*}{ Sugarbush } & yes & 28 \\
\hline & no & 7 \\
\hline \multirow[t]{2}{*}{ Harvest type } & whole-tree harvest & 25 \\
\hline & non-whole-tree harvest & 10 \\
\hline \multirow[t]{6}{*}{ Treatment } & crop tree release & 8 \\
\hline & group selection & 4 \\
\hline & shelterwood & 4 \\
\hline & single-tree selection & 6 \\
\hline & single-tree/small-group selection combination & 3 \\
\hline & thinning from below (incl. some co-dominant removal) & 10 \\
\hline \multirow{4}{*}{$\begin{array}{l}\text { Marked by professional } \\
\text { forester } \\
\text { Winter-only harvest }\end{array}$} & yes & 28 \\
\hline & no & 7 \\
\hline & yes & 16 \\
\hline & no & 19 \\
\hline \multirow[t]{3}{*}{ Cutting equipment } & chainsaw & 10 \\
\hline & shear & 20 \\
\hline & both & 5 \\
\hline \multirow[t]{4}{*}{ Skidders } & cable & 15 \\
\hline & grapple & 10 \\
\hline & both & 7 \\
\hline & none & 3 \\
\hline \multirow[t]{2}{*}{ Pulp also generated } & yes & 16 \\
\hline & no & 19 \\
\hline \multirow{4}{*}{ End user of chips } & municipal & 24 \\
\hline & municipal/school & 2 \\
\hline & pulp-mill or municipal/pulp-mill & 3 \\
\hline & not applicable (no chips) & 6 \\
\hline Bioenergy percentage & continuous & 35 \\
\hline
\end{tabular}

$\dagger$ All variables are categorical, except the percentage of the harvested volume used for bioenergy (which is continuous).

$\$$ For example, Current Use or Biomass Crop Assistance Program.

$\S$ Land certification (e.g., American Tree Farm, Forest Stewardship Council, Northeast Organic Farming Association, Vermont Family Forests). Each promotes a degree of sustainable management practices, but with widely varying standards.

- Percentage of total harvested volume used for bioenergy.

tion - at bole-only removals. Such recruitment enhances habitat provisioning and niche diversification for a range of species (Harmon et al. 1986, Schiegg 2000, McKenny et al. 2006). Further, slash retention may help reduce soil compaction and erosion from harvesting equipment (Hutchings et al. 2002, Han et al. 2009) and minimize losses to nutrient capitals (Helmisaari et al. 2011). Thus, our results suggest a possible impairment of these functions at WTH sites. However, a minority (eight) of the WTH sites did not show large DCWD reductions, suggesting that some operators are retaining a level of downed woody debris structure.

At WTH sites, it is the reduction in late decay stage (3-5) DCWD that primarily accounts for the negative percentage difference in total DCWD. Heavier harvesting equipment and more extensive skid-trail networks associated with whole-tree harvests may have destroyed more fragile, late decay stage DCWD, a general harvesting impact found previously by some researchers (McGee et al. 1999) but not by others (Fraver et al. 2002). We recognize that dense hay-scented fern (Dennstaedtia punctilobula) cover at more intensively harvested and therefore open stands may have resulted in under-sampling of less apparent, well-decayed DCWD.

Downed-crown density.-We know of no previous studies that specifically investigate the abundance of downed tree crowns in the bioenergy context. Downed crowns, whether felled or naturally downed, represent DCWD recruitment and an input to the forest floor of nutrient-rich foliage and twigs, particularly during the growing season (Hornbeck and Kropelin 1982, Yanai 1998). Sites that were neither whole-tree harvested nor had any material allocated to bioenergy had twice as 


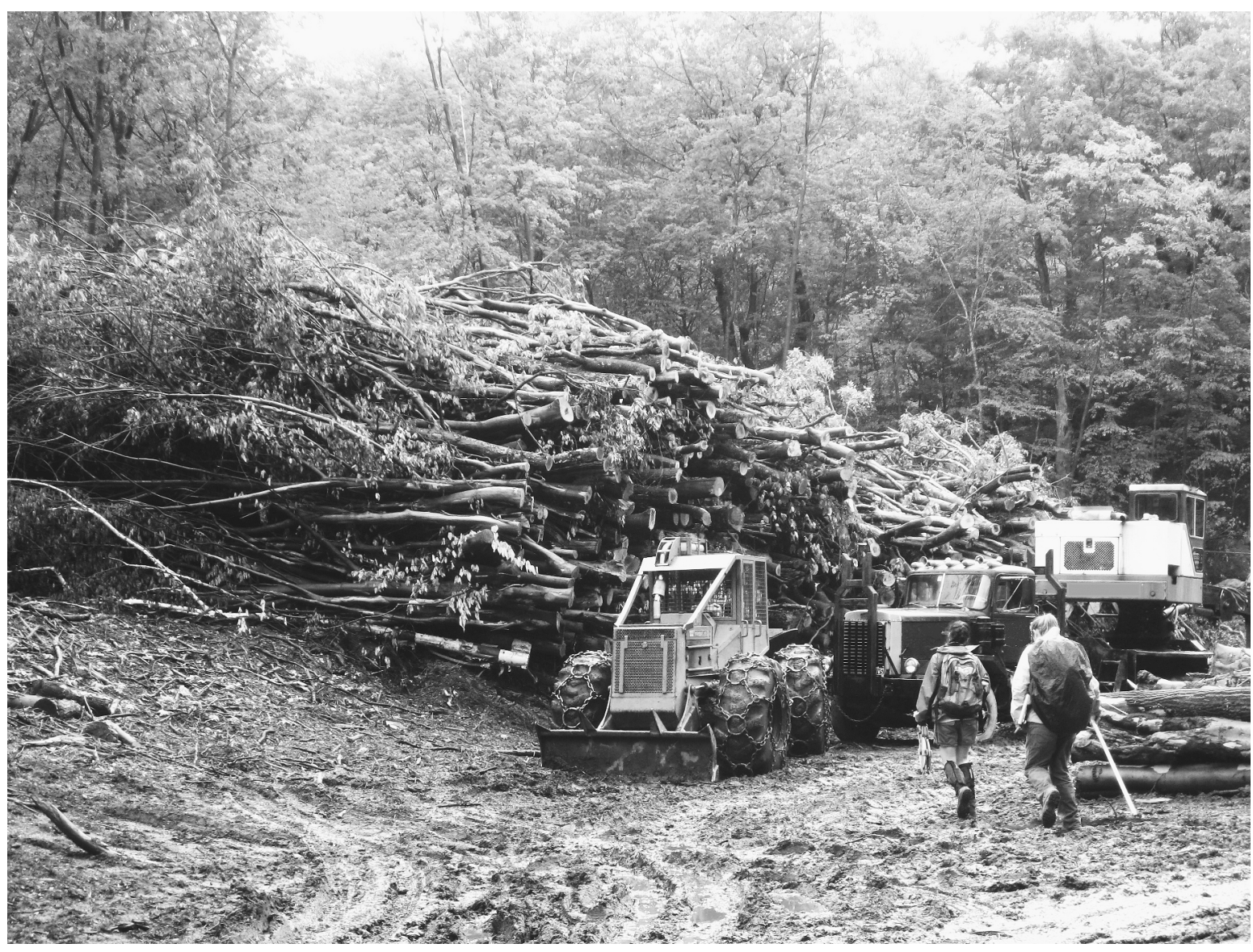

Plate 1. Upper tree stems and crowns removed at one of the study sites using whole tree harvesting methods and piled at the landing for use as bioenergy in Vermont, USA. The photograph has been altered to remove logos on equipment. Photo credit: C. E. Littlefield.

many and over five times as many felled crowns in harvested areas as non-WTH sites with bioenergy and WTH sites, respectively. The lower abundance of felled crowns at WTH sites is to be expected as whole-tree harvests remove entire trees. Fewer felled crowns at bioenergy sites that were not whole-tree harvested may indicate that operators still removed a portion of otherwise unmerchantable upper boles to be chipped for bioenergy. Thus, our results suggest that bioenergy sites-WTH or not- - have reduced potential for DCWD recruitment given extensive tree crown removal.

\section{Diameter-class distribution and tree density}

All of our sites exhibited negative exponential diameter distributions, though the post-harvest stand structure of sites that were not whole-tree harvested better approximated a balanced, negative exponential diameter distribution often associated with uneven-aged management (e.g., Smith 1986, Goodburn and Lorimer1999). Further, total tree density was consistently greater for non-WTH sites and for sites from which no bioenergy was generated. This may be attributable to the fact that one-third of the WTH sites were either shelterwood or larger group selection cuts averaging $-61 \%$ difference in net cubic volume, while all other harvest treatments averaged $-34 \%$ difference in net cubic volume. However, this finding is also consistent with an interpretation that bioenergy harvests are reducing stand density to a greater degree because of an emphasis on removing large, poor-quality stems (Lattimore et al. 2009, Janowiak and Webster 2010), which often are not economical to thin in a conventional operation (Sabourin et al. 1992, Buccholz et al. 2009). Additionally, larger cutting equipment tends to open stands to a greater degree. Use of larger machinery was correlated with WTH operations (Mika and Keeton 2012) and may thus help explain lower tree densities at WTH sites.

\section{Relating bioenergy volume and structural indicators}

Harvesting impacts were highly variable across the range of volumes allocated to bioenergy, as illustrated by the variability in harvest-induced contrast in aboveground live biomass, $H$ index values, and snag densities. Of particular interest is that snags were removed at 
nearly three quarters of all the sites sampled (both bioenergy and non-bioenergy), which is consistent with prior studies demonstrating a decrease in snag abundance and at WTH bioenergy sites (Briedis et al. 2011) and in partially cut northern hardwood stands (Goodburn and Lorimer 1998, McGee et al. 1999). Despite increased appreciation of the ecological importance of snags in the literature (e.g., Hunter 1999), operators may still be removing snags out of occupational safety concerns (Vanderwel et al. 2006), to free growing space, or because they do not view snags as contributing to the health of the growing stock (McGee et al. 1999). A portion of sites did exhibit higher snag densities in harvested areas compared to reference areas. In these cases, tree mortality, and therefore snag recruitment, may have occurred since harvest due to injury sustained during harvesting or exposure-induced mortality (Cline et al. 1991, Angers et al. 2005).

A second overarching pattern that emerges in evaluating structural impacts across a range of bioenergy removal volumes is the fact that that the bulk of the harvested volume at the majority of the study sites was not going to bioenergy production but instead to sawlogs, cordwood, and, in several instances, pulp and veneer. This signals that bioenergy harvesting very often occurs in conjunction with, or secondarily to, other harvesting objectives (Sabourin et al. 1992, Manley and Richardson 1995, Cook and O'Laughlin 2011).

\section{Factors predicting post-harvest structure}

To sufficiently safeguard important elements of stand structure in the context of bioenergy harvesting, it is helpful to understand which site- and harvest-specific factors drive post-harvest structure. In our data set the more intensively harvested sites (e.g., shelterwood and large group selection sites) exhibited the greatest positive contrast in DCWD volume (harvested cf. reference areas), as shown in our CART results; these sites also exhibited the greatest negative contrast in $H$ index values. This is plausible because the volume removed at these sites (over two-thirds of which were WTH) exceeded that removed at alternatively treated sites. Even if slash was not intentionally retained at WTH sites, the sheer number of trees cut and skidded to the landing may have recruited DCWD while effectively homogenizing the live-tree stand structure.

The first CART model also parsed out the sites thinnedfrom-below as exhibiting the greatest positive contrast in DCWD volume, which was likely driven by slash retention stipulations at nearly one-third of these sites. Four of these sites had no volume allocated to bioenergy and five of these sites were not whole-tree harvested. Only two of the sites with such stipulations were certified, which may help explain, in part, why noncertified sites had, on average, a more positive contrast in DCWD volume than certified sites. Otherwise, this may indicate that woody debris retention standards in sustainable-forest management certifications are not consistently followed (Foster et al.
2008). Another interesting finding pertains to sugarbush conversion cuts, which were categorized as crop-tree releases. At these sites relatively less DCWD was likely retained to facilitate sugaring operations. The negative contrast in DCWD volumes at crop-tree releases may thus, in part, be due to these sugarbush conversion traits.

Our CART results suggested that the impacts on DCWD volume and live tree structural complexity (i.e., $H$ index) were relatively lower when cable skidders (e.g., John Deere 540G-III) were used instead of grapple skidders (e.g., John Deere 648H). Use of the latter emerged as a primary determinant of reductions in DCWD volume and as a secondary determinant of reductions in $H$ index values after end users of harvested material. Sites from which material was earmarked exclusively for municipal bioenergy use were among the highest in terms of negative impact on $H$ index values, particularly when paired with use of larger skidding machinery. Conversely, when woody material was harvested primarily for smaller-scale bioenergy uses, there were less dramatic changes in aggregate live-tree structural complexity. We cannot infer a direct explanation for this pattern, although it is plausible that bioenergy harvesting intensity is related to wood procurement demand and the removal efficiency afforded by larger machinery.

Thus, while the percentage of total harvested volume allocated to bioenergy was not a primary determinant in either DCWD or $H$ index responses, it may additionally explain harvest-induced contrasts in these metrics. Greater allocation of harvested volume to bioenergy was positively correlated with grapple skidder use and municipal bioenergy use, and therefore may have an indirect relationship with DCWD and $H$ index reductions. Similarly, the WTH vs. non-WTH classification of sites did not emerge as a primary determinant, but these harvest types may also have an indirect relationship with DCWD and $H$ index reductions. For instance, 14 of the 15 sites at which a grapple skidder was used exclusively were whole-tree harvested. What is clear from these CART analyses is that post-harvest structural condition depends on the interaction of multiple harvest- and sitespecific factors.

\section{Management implications for bioenergy harvesting}

Potential ecological impacts of bioenergy harvesting have been of concern for several decades (e.g., Van Hook et al. 1982, Chadwick et al. 1986, Lattimore et al. 2009). Minimizing potential negative consequences is a major focus of policy discussions and academic research (Janowiak and Webster 2010, Manomet Center for Conservation Sciences 2010, Gunn et al. 2012). While previous research has tended to downplay the variability evident in harvesting practices - for instance, by strictly categorizing harvests as either bioenergy or nonbioenergy, or whole-tree vs. non-whole tree (e.g., Mann et al. 1988, Yanai 1998, Briedis et al. 2011)-our research highlights the importance of considering bio- 
energy as a continuous variable in the context of multiple harvest objectives. Proposed bioenergy harvesting guidelines must therefore be evaluated within the larger context of sustainable forest management, and must be grounded in rigorous scientific analyses that examine a range of stand conditions, silvicultural objectives, and harvesting practices. The need for wellgrounded harvesting guidelines is particularly important given the industry trend towards increased mechanization and intensification of bioenergy harvesting practices across larger areas to achieve economies of scale (Abbas et al. 2011, Munsell et al. 2011).

Our results suggest that structural retention may decrease available bioenergy harvest volume. Understanding these impacts is essential for regional supply estimates. For example, applying retention guidelines (see Benjamin 2010) in Maine (USA) reduces available woody biomass estimates from 11.7 million green tons to 3.8 million green tons (Wagner et al. 2011; 1 short ton $=907.19 \mathrm{~kg}$ ). Imposing model constraints to reflect guidelines significantly reduced bioenergy supply estimates for 16 states in the western United States (Cook and O'Laughlin 2011). Consideration of retention standards has been integral to supply estimates in Australia (Fung et al. 2002), Italy (Freppaz et al. 2004), and the European Union (United Nations Economic Commission for Europe 2011).

Findings from this study can inform development of retention guidelines for bioenergy harvesting in the northern hardwood region. Similar retention approaches are relevant in other forest types, such as spruce-fir (Briedis et al. 2011), southern pine (Eisenbies et al. 2009), Australian eucalyptus (Fung et al. 2002), and Nordic boreal (Helmisaari et al. 2011). Our dataset indicates that important structural elements are not consistently retained, particularly at sites that are whole-tree harvested. Nonbole materials (e.g., tree tops) removed in WTH operations represent foregone DCWD and FWD, yet demand for such materials - and low-grade wood - may increase as the market for bioenergy grows (Sabourin et al. 1992, Manley and Richardson 1995, Buccholz et al. 2009). Guidelines may therefore encourage retention of existing snags and downed dead wood to a higher degree and as consistent with worker-safety standards. For instance, we recommend the retention of at least a portion of tree crowns even at WTH sites. We also recommend careful attention to choice of harvesting and skidding machinery, which were strongly correlated with impacts on stand structure.

In conclusion, the forestry profession should be heartened by the high standards exhibited by some operators. For example, one professional forestry organization recommends retention of at least $25 \%$ of slash, tops, and limbs during bioenergy operations (Forest Guild Biomass Working Group 2010). We found that $30 \%$ of the WTH bioenergy harvests and all non-WTH bioenergy operations sampled met or exceeded this standard. The bar has thus been set, and guidelines can play a positive role encouraging others to improve harvesting practices.

\section{ACKNOWLEDGments}

This research was supported by grants from the Northeastern States Research Cooperative and the USDA McIntireStennis Forest Research Program. It would not have been possible without the assistance of Donald Tobi and participating foresters and landowners. The authors are particularly grateful to the field crew, including Anna Mika, Isabel Beavers, and Emily Potter. Thoughtful reviews and input were provided by Charlie Bettigole, Kimberly Coleman, Spencer Paxson, Shelly Rayback, and the Carbon Dynamics Laboratory at the University of Vermont.

\section{Literature Cited}

Abbas, D., D. Current, M. Phillips, R. Rossman, H. Hoganson, and K. N. Brooks. 2011. Guidelines for harvesting forest biomass for energy: a synthesis of environmental considerations. Biomass and Bioenergy 35:4538-4546.

Allen, C. D., M. Savage, D. A. Falk, K. F. Suckling, T. W. Swetnam, T. Schulke, P. B. Stacey, P. Morgan, M. Hoffman, and J. T. Klingel. 2002. Ecological restoration of southwestern ponderosa pine ecosytems: a broad perspective. Ecological Applications 12:1418-1433.

Angers, V. A., C. Messier, M. Beaudet, and A. Leduc. 2005. Comparing composition and structure in old-growth and harvested (selection and diameter-limit cuts) northern hardwood stands in Quebec. Forest Ecology and Management 217:275-293.

Ashley, B. S. 1999. Reference handbook for foresters. NA-FR15. United States Department of Agriculture State and Private Forestry, Northeastern Area, Morgantown, West Virginia, USA.

Benjamin, J. G., editor. 2010. Considerations and recommendations for retaining woody biomass on timber harvest sites in Maine. Miscellaneous Publication 761. Maine Agricultural and Forest Experiment Station, University of Maine, Orono, Maine, USA.

Bilby, R. E., and G. E. Likens. 1980. Importance of organic debris dams in the structure and function of stream ecosystems. Ecology 61:1107-1113.

Bowman, J. C., D. Sleep, G. J. Forbes, and M. Edwards. 2000. The association of small mammals with coarse woody debris at $\log$ and stand scales. Forest Ecology and Management 129:119-124.

Breiman, L., J. H. Friedman, R. Olshen, and C. Stone. 1984. Classification and regression trees. Wadsworth International Group, Belmont, California, USA.

Briedis, J., J. S. Wilson, J. G. Benjamin, and R. G. Wagner. 2011. Biomass retention following whole-tree, energy wood harvests in central Maine: adherence to five state guidelines. Biomass and Bioenergy 35:3552-3560.

Buccholz, T., V. A. Luzadis, and T. A. Volk. 2009. Sustainability criteria for bioenergy systems: results from an expert survey. Journal of Cleaner Production 17:S86-S98.

Chadwick, N. L., D. R. Progulske, and J. T. Finn. 1986. Effects of fuelwood cutting on birds in southern New England. Journal of Wildlife Management 50:398-405.

Cline, M. L., and B. F. Hoffman, M. Cyr, and B. William. 1991. Stand damage following whole-tree partial cutting in northern forests. Nothern Journal of Applied Forestry 8:7276.

Cook, P. S., and J. O'Laughlin. 2011. Forest biomass supply analysis for Western states by county: final report to the Western Governors' Association. University of Idaho's College of Natural Resources, Moscow, Idaho, USA.

Crow, T. R., D. S. Buckley, E. A. Nauertz, and J. C. Zasada. 2002. Effects of management on the composition and 
structure of northern hardwood forests in upper Michigan. Forest Science 48:129-145.

De'ath, G., and K. E. Fabricius. 2000. Classification and regression trees: a powerful yet simple technique for ecological data analysis. Ecology 81:3178-3192.

DeGraaf, R. M., J. B. Hestbeck, and M. Yamasaki. 1998. Associations between breeding bird abundance and stand structure in the White Mountains, New Hampshire and Maine, USA. Forest Ecology and Management 103:217-233.

Demchik, M. C., D. Abbas, D. Current, D. Arnosti, M. Theimer, and P. Johnson. 2009. Combining biomass harvest and forest fuel reduction in the Superior National Forest, Minnesota. Journal of Forestry 107:235-241.

Eisenbies, M., E. Vance, W. Aust, and J. Seiler. 2009. Intensive utilization of harvest residues in southern pine plantations: quantities available and implications for nutrient budgets and sustainable site productivity. BioEnergy Research 2:90-98.

Evans, A. M., and A. J. Finkral. 2009. From renewable energy to fire risk reduction: a synthesis of biomass harvesting and utilization case studies in US forests. Global Change Biology. Bioenergy 1:211-219.

Evans, A. M., and R. T. Perschel. 2009. An Assessment of Biomass Harvesting Guidelines. Forest Guild, Santa Fe, New Mexico, USA.

Forest Guild Biomass Working Group. 2010. Forest biomass retention and harvesting guidelines for the Northeast. Forest Guild, Santa Fe, New Mexico, USA. www.forestguild.org/ publications/research/2010/FG_Biomass_Guidelines_NE.pdf

Foster, B. C., D. Wang, and W. S. Keeton. 2008. An exploratory, post-harvest comparison of ecological and economic characteristics of Forest Stewardship Council certified and uncertified northern hardwood stands. Journal of Sustainable Forestry 26:171-191.

Fraver, S., R. G. Wagner, and M. Day. 2002. Dynamics of coarse woody debris following gap harvesting in the Acadian forest of central Maine, U.S.A. Canadian Journal of Forest Research 32:2094-2105.

Freedman, B., V. Zelazny, D. Beaudette, T. Fleming, S. Flemming, G. Forbes, G. Johnson, and S. Woodley. 1996. Biodiversity implications of changes in the quantity of dead organic matter in managed forests. Environmental Reviews 4:238-265.

Freppaz, D., R. Minciardi, M. Robba, M. Rovatti, R. Sacile, and A. Taramasso. 2004. Optimizing forest biomass exploitation for energy supply at a regional level. Biomass and Bioenergy 26:15-25.

Fung, P. Y. H., M. U. F. Kirschbaum, R. J. Raison, and C. Stucley. 2002. The potential for bioenergy production from Australian forests, its contribution to national greenhouse targets and recent developments in conversion processes. Biomass and Bioenergy 22:223-236.

Goodburn, J. M., and C. G. Lorimer. 1998. Cavity trees and coarse woody debris in old-growth and managed northern hardwood forests in Wisconsin and Michigan. Canadian Journal of Forest Research 28:427-438.

Goodburn, J. M., and C. G. Lorimer. 1999. Population structure in old-growth and managed northern hardwoods: an examination of the balanced diameter distribution concept. Forest Ecology and Management 118:11-29.

Gunn, J. A., D. J. Ganz, and W. S. Keeton. 2012. Biogenic vs. geologic carbon emissions and forest biomass energy production. Global Change Biology-Bioenergy 4:239-242.

Han, S. K., H. Han Sup, D. Page-Dumroese, and L. R. Johnson. 2009. Soil compaction associated with cut-to-length and whole-tree harvesting of a coniferous forest. Canadian Journal of Forest Research 39:976-989.

Harmon, M. E., W. K. Ferrell, and J. F. Franklin. 1990. Effects on carbon storage of conversion of old-growth forests to young forests. Science 247:699-702.

Harmon, M. E., and B. Marks. 2002. Effects of silvicultural practices on carbon stores in Douglas-fir-western hemlock forests in the Pacific Northwest, U.S.A.: results from a simulation model. Canadian Journal of Forest Research 32:863-877.

Harmon, M. E., et al. 1986. Ecology of coarse woody debris in temperate ecosystems. Advances in Ecological Research 15:133-302.

Helmisaari, H.-S., K. H. Hanssen, S. Jacobson, M. Kukkola, J. Luiro, A. Saarsalmi, P. Tamminen, and B. Tveite. 2011. Logging residue removal after thinning in Nordic boreal forests: long-term impact on tree growth. Forest Ecology and Management 261:1919-1927.

Hornbeck, J. W., and W. Kropelin. 1982. Nutrient removal and leaching from a whole-tree harvest of northern hardwoods. Journal of Environmental Quality 11:309-316.

Hornbeck, J. W., C. T. Smith, Q. W. Martin, L. M. Tritton, and R. S. Pierce. 1990. Effects of intensive harvesting on nutrient capitals of three forest types in New England. Forest Ecology and Management 30:55-64.

Hunter, M. L., Jr., editor. 1999. Maintaining Biodiversity in Forested Ecosystems. Cambridge University Press, Cambridge, UK.

Hutchings, T. R., A. J. Moffat, and C. J. French. 2002. Soil compaction under timber harvesting machinery: a preliminary report on the role of brash mats in its prevention. Soil Use and Management 18:34-38.

Janowiak, M. K., and C. R. Webster. 2010. Promoting ecological sustainability in woody biomass harvesting. Journal of Forestry 108:16-23.

Keddy, P. A., and C. G. Drummond. 1996. Ecological properties for the evaluation, management, and restoration of temperate deciduous forest ecosystems. Ecological Applications 6:748-762.

Keeton, W. S., C. E. Kraft, and D. R. Warren. 2007. Mature and old-growth riparian forests: structure, dynamics, and effects on Adirondack stream habitats. Ecological Applications 17:852-868.

Krankina, O. N., and M. E. Harmon. 1994. The impact of intensive forest management on carbon stores in forest ecosystems. World Resource Review 6:161-177.

Lattimore, B., C. T. Smith, B. D. Titus, I. Stupak, and G. Egnell. 2009. Environmental factors in woodfuel production: opportunities, risks, and criteria and indicators for sustainable practices. Biomass and Bioenergy 33:1321-1342.

Leniere, A., and G. Houle. 2006. Response of herbaceous plant diversity to reduced structural diversity in maple-dominated (Acer saccharum Marsh.) forests manged for sap extraction. Forest Ecology and Management 231:94-104.

Littlefield, C. E. 2011. Effects of wood bioenergy harvesting on ecologically important stand structure characteristics in northern hardwood forests. Masters Thesis. University of Vermont, Burlington, Vermont, USA.

Manaras-Smith, K., W. S. Keeton, T. M. Donovan, and B. Mitchell. 2008. Stand-level forest structure and avian habitat: scale dependencies in prediction occurrence in a heterogeneous forest. Forest Science 54:36-46.

Manley, A., and J. Richardson. 1995. Silviculture and economic benefits of producing wood energy from conventional forestry systems and measures to mitigate negative impacts. Biomass and Bioenergy 9:89-105.

Mann, L. K., D. W. Johnson, D. C. West, D. W. Cole, J. W. Hornbeck, C. W. Martin, H. Riekerk, C. T. Smith, W. T. Swank, L. M. Tritton, and D. H. Van Lear. 1988. Effects of whole-tree and stem-only clearcutting on postharvest hydrologic losses, nutrient capital, and regrowth. Forest Science 34:412-428.

Manomet Center for Conservation Sciences. 2010. Biomass sustainability and carbon policy study. Report to the Commonwealth of Massachusetts Department of Energy Resources. NCI-2010-03. Manomet Center for Conservation Sciences, Brunswick, Maine, USA. 
McElhinny, C., P. Gibbons, C. Brack, and J. Bauhus. 2005. Forest and woodland stand structural complexity: its definition and measurement. Forest Ecology and Management 218:1-24.

McGarigal, K., S. Cushman, and S. Stafford. 2000. Multivariate statistics for wildlife and ecology research. SpringerVerlag, New York, New York, USA.

McGee, G. G., and J. P. Birmingham. 1997. Decaying logs as germination sites in northern hardwood forests. Northern Journal of Applied Forestry 14:178-182.

McGee, G. G., D. J. Leopold, and R. D. Nyland. 1999. Structural characteristics of old-growth, maturing, and partially cut northern hardwood forests. Ecological Applications 9:1316-1329.

McKenny, H. C., W. S. Keeton, and T. M. Donovan. 2006. Effects of structural complexity enhancement on eastern redbacked salamander (Plethodon cinereus) populations in northern hardwood forests. Forest Ecology and Management 230:186-196.

Mika, A., and W. S. Keeton. 2012. Factors contributing to carbon fluxes from bioenergy harvests in the U.S. northeast: an analysis using field data. GCB Bioenergy, in press.

Munsell, J. F., S. M. Barrett, and M. C. Bolding. 2011. An exploratory study of biomass harvesting among logging firms in Virginia and North Carolina. Forest Science 57:427-434.

Nunery, J. S., and W. S. Keeton. 2010. Forest carbon storage in the northeastern United States: net effects of harvesting frequency, post-harvest retention, and wood products. Forest Ecology and Management 259:1363-1375.

Oliver, C. D., and B. C. Larson. 1996. Forest Stand Dynamics. John Wiley and Sons, New York, New York, USA.

Pommerening, A. 2002. Approaches to quantifying forest structures. Forestry 75:305-324.

Richardson, J., P. Hakkila, A. T. Lowe, and C. T. Smith, editors. 2002. Bioenergy from sustainable forestry: guiding principles and practice. Kluwer Academic Publishers, Boston, Massachusetts, USA.

Sabourin, M., G. D. Puttock, and J. Richardson. 1992. Forest management strategies for producing wood for energy from conventional forestry systems. Biomass and Bioenergy 2:105119.

SAS Institute. 2011. JMP, version 9. SAS Institute, Cary, North Carolina, USA.

Schiegg, K. 2000. Effects of dead wood volume and connectivity on saproxylic insect species diversity. Ecoscience 7:290298.

Shiver, B. D., and B. E. Borders. 1996. Sampling techniques for forest resource inventory. John Wiley and Sons, New York, New York, USA.

Smith, C. T. 1995. Environmental consequences of intensive harvesting. Biomass and Bioenergy 9:161-179.

Smith, D. M. 1986. Practice of silviculture. Eighth edition. John Wiley and Sons, New York, New York, USA.

Smith, K. J., W. S. Keeton, M. Twery, and D. Tobi. 2008. Understory plant response to alternative forestry practices in northern hardwood-conifer forests. Canadian Journal of Forest Research 38:1-17.

Sollins, P., S. P. Cline, T. Verhoeven, D. Sachs, and G. Spycher. 1987. Patterns of log decay in old-growth Douglas-fir forest. Canadian Journal of Forest Research 17:1585-1595.
Spence, J. R., D. W. Langor, and J. M. Jacobs. 2007. Variable retention harvest of white spruce stands and saproxylic beetle assemblages. Canadian Journal of Forest Research 37:16311642.

Spies, T. A. 1998. Forest structure: a key to the ecosystem. Northwest Science 72:34-39.

Staudhammer, C. L., and V. M. LeMay. 2001. Introduction and evaluation of possible indices of stand structural diversity. Canadian Journal of Forest Research 31:11051115.

Stupak, I., et al. 2007. Sustainable utilisation of forest biomass for energy-possibilities and problems: policy, legislation, certification, and recommendations and guidelines in the Nordic, Baltic, and other European countries. Biomass and Bioenergy 31:666-684.

Thiffault, E., K. D. Hannam, D. Pare, B. D. Titus, P. W. Hazlett, D. G. Maynard, and S. Brais. 2011. Effects of forest biomass harvesting on soil productivity in boreal and temperate forests - a review. Environmental Reviews 19:278-309.

TIBCO Software. 2010. S-Plus, version 8.2. TIBCO Software, Palo Alto, California, USA.

Twery, M. J., P. D. Knopp, S. A. Thomasma, H. M. Rauscher, D. E. Nute, W. D. Potter, F. Maier, J. Wang, M. Dass, H. Uchiyama, A. Glende, and R. E. Hoffman. 2005. NED-2: A decision support system for integrated forest ecosystem management. Computers and Electronics in Agriculture 49:24-43.

United Nations Economic Commission for Europe. 2011. European forest sector outlook study II. 2010-2030. United Nations, Geneva, Switzerland.

Vanderwel, M. C., J. P. Caspersen, and M. E. Woods. 2006. Snag dynamics in partially harvested and unmanaged northern hardwood forests. Canadian Journal of Forest Research 36:2769-2779.

Van Hook, R. I., D. W. Johnson, D. C. West, and L. K. Mann. 1982. Environmental effects of harvesting forests for energy. Forest Ecology and Management 4:79-94.

Van Wagner, C. E. 1968. The line intersect method in forest fuel sampling. Forest Science 15:20-26.

Wagner, R. G., J. G. Benjamin, A. R. Weiskittel, and K. M. Laustsen. 2011. Factors affecting increases in biomass production from Maine forests. Presentation to Woody Biomass Energy Research Symposium for the Northern Forest. 28-30 April 2011, University of Vermont, Burlington, Vermont, USA. http://www.uvm.edu/ cfcm/symposium/ ?Page=Wagner.html

Westerling, A. L., H. G. Hidalgo, D. R. Cayan, and T. W. Swetnam. 2006. Warming and earlier spring increase western U.S. forest wildfire activity. Science 313:940-943.

Woodall, C., and M. S. Williams. 2005. Sampling protocol, estimation, and analysis procedures for the down woody material indicator of the FIA program. GTR-NC-256. United States Department of Agriculture, Forest Service, North Central Research Station, St. Paul, Minnesota, USA.

Yanai, R. D. 1998. The effect of whole-tree harvest on phosphorus cycling in a northern hardwood forest. Forest Ecology and Management 104:281-295. 